\title{
Predicting Changing Pattern: Building Model for Consumer Decision Making in Digital Market
}

\author{
Anil Kumar \\ School of Management, BML Munjal University, \\ Gurgaon, India \\ Email: anilror@gmail.com \\ Sachin Kumar Mangla \\ Department of Mechanical Engineering, Graphic Era University, \\ Dehradun, India \\ Email: sachinmangl@gmail.com
}

\author{
Sunil Luthra \\ Department of Mechanical Engineering, \\ State Institute of Engineering \& Technology (Formerly known as Government Engineering \\ College), Nilokheri, India \\ Email: sunilluthra1977@gmail.com
}

Nripendra P. Rana*

Associate Professor in Information Systems \& Deputy Head of Department of Business, School of Management, Swansea University, Swansea, United Kingdom

Email: nrananp@gmail.com

Yogesh K. Dwivedi

Director of Emerging Markets Research Centre, School of Management, Swansea University, Swansea, United Kingdom Email: ykdwivedi@gmail.com

*Corresponding Author

\begin{abstract}
Purpose - Consumers have the multiple options to choose their products and services, which have a significant impact on the pattern of consumer decision making in digital market and further increases the challenges for the service providers to predict their buying pattern. In this sense, the present work efforts to propose a structural hierarchy model for analysing the changing pattern of consumer decision making in digital market by taking an Indian context.

Design/methodology/approach - To accomplish the objectives, the research is conducted in two phases. An extensive literature review is performed in the first phase to list the factors related to the changing pattern of consumer decision making in digital market and then fuzzy Delphi method is applied to finalize the factors. In the second phase, fuzzy Analytic Hierarchy Process (AHP) is employed to find the priority weights of finalized factors. The fuzzy set theory allows capturing the vagueness in the data.

Findings - The findings obtained in this study shows that consumers are much conscious about innovative and trendy products as well as brand and quality therefore, the service providers must think about these two most important factors so that they can able to retain their consumer in their online portal.

Practical implications - The analysis shows that 'innovative and trendy' is the first priority factor for the consumers followed by 'brand and quality' and 'fulfilment and time energy'.
\end{abstract}


The proposed model can help the marketers and service providers in predicting customers' preferences and their changing pattern efficiently under vague surroundings. The outcomes of this research work not only help the service provider to update their products and services according to consumers' needs but can also help them to increase profit and minimize their risk.

Originality/value - This work contributes to consumer research literature focusing on problem evaluation in the context of changing pattern of consumer decision making in digital era.

Keywords: Consumer behaviour; Fuzzy Delphi; Changing pattern; Digital market; Fuzzy AHP; Hierarchy model

Paper Type: Research Paper

\section{Introduction}

The changes are accelerating than never before and Internet is becoming the core need of businesses in this era of e-generation (Abbasi et al., 2011; Fullam, 2017; Tan et al., 2010). Internet is having the key potential of changing the way people are involved in businesses and even the society they live in (Doherty and Ellis-Chadwick, 2010). Internet is bridging the gap irrespective of any geographical limitations, providing new opportunities worldwide. Therefore, the digital platform is being used by marketers for identifying their opportunities that help them in promoting, communicating and distributing their products to the end users (Confos et al., 2016; Shaouf et al., 2017). Internet serves a common market that is not only used for the exchange of goods and services but also responsible for interaction between consumer and businesses (Srinivasan et al., 2016). Notably, about $49.8 \%$ of the world population are able to access Internet, out of which $45.2 \%$ are from Asia, and interestingly Indian population Internet penetration contributes $24.7 \%$ of the Asian population and $34.4 . \%$ of the world population.

Consumers are transforming their way of the traditional purchasing ( $\mathrm{Wu}$ et al. 2016). This brings out an exponential growth of Internet based purchasing volume simultaneously changing the pattern of consumers' decision making. Customers are relying on Internet for their daily needs and even customizing their needs with the help of digital technology. In this sense, maintenance of customer relationship becomes the core operation of any business (Royle and Laing, 2014).

The advancements and penetration of the technologies, consumer behaviour and their hectic schedules, and trust on the e-commerce environment are some of the driving factors responsible for changing pattern of consumers' decision making (Srinivasan et al., 2016; Wu et al. 2016). This changing pattern in consumer behaviour poses significant challenges for the online service providers. Online retailers should figure out the strategies considering the 
factors of further improvements of maintaining their consumer trust. They need to have a fair understanding of the changing patterns and expectations of the consumers. The current features allow the consumers to walk through their purchases, help them in searching appropriating option, gather sufficient information from the specifications and comparisons, evaluate the available options and then make the decision to purchase (Filieri, 2015). Ecommerce tools are helping the consumers in simplifying the process of buying (Khare, 2012; Richa 2012). Further, ratings and reviews of a product also influence the purchasing decision and shopping behaviour of consumers (Filieri, 2015; Zhu and Zhang, 2010).

Consumer's decision making patterns are changing rapidly due to the ease of information transmitted through online facilities, and hence the marketers should keep a unique marketing mix in the process of formulating strategies for consumer attraction, loyalty and retention. This requires proper understanding of the consumer decision making pattern as well as their satisfaction level during online purchasing. Another factor contributing to the e-commerce success is the availability of the various payment options for the consumers. Online platforms are serving the marketers to get closer to their consumer, which increase their revenues as well. Very few previous studies are available related to customer decision making in digital market (McDonald and Wilson, 2016; Meeran et al., 2017; Vassileva, 2017; Xiang et al., 2015), which determines that for sustain business success, the service providers have the capability to predict consumer behaviour properly. Therefore, in the era of big data revolution, synthesizing information about consumer's changing pattern of their behaviour is of paramount importance for making the proper marketing strategy in the digital market (Ashman et al., 2015; Akter and Wamba, 2016; Erevelles et al., 2016). This work contributes to consumer research literature in the context of the changing pattern of consumers' decision making in the digital market and develop a hierarchy model.

This research is provoked by the changeable consumer behaviour patterns i.e. offline to online, which depends on the purchasing environment. In case of e-commerce business, there is huge competition and multiple options are available for customers in buying. In such cases, customer decision making pattern is very important to decide the business success (Erevelles et al., 2016; Meeran et al., 2017). In doing so, the marketers can properly identify the customers' touch points in the decision-making process and formulates further strategies to attract and retain more customers. E-commerce is an online platform based business, which offers logical means to the customers at each moment with just a single click or touch, and therefore it is highly necessary for the marketers to know about customer's behaviour in digital markets and get them more and more involved. When the changes happen in consumer preferences and buying taste, proper understanding about these changes of preference can 
help the service provider to make proper marketing strategy (McDonald and Wilson, 2016). In addition, internet penetration is increasing rapidly and its tremendous impact on online buying behaviour of consumers especially on their online buy behaviour. Now they have many options for searching, recommending etc. that thing directly impacting on their final buying decision making. According to a survey report, buying decision of $67 \%$ of consumer is influenced by online review, $85 \%$ of the sales generated by social media, therefore, to understand the changing pattern of consumers decision making is very important for the online service providers so that they can predict their consumers well and make appropriate marketing strategy to retain them (Erevelles et al., 2016; Vassileva, 2017).

This study is based on problem evaluation in the context of changing pattern of consumer decision making in digital market. It should be noted that there are several factors responsible for influencing consumer decision making pattern and a subsequent analysis of these factors would be useful for the online service providers in deducing the consumer pattern. There are studies predicting customer behaviour and preferences across various sectors, creating a gap in understanding why so the behaviour and preference is (McDonald and Wilson, 2016; Meeran et al., 2017). The worthiness of study is twofold; first, when the service provider knows about their consumers well and their changing pattern, definitely that understanding helps them not only to provide the products/services according their changing needs but also help them to make their marketing strategy in a way so that they can maximize their profit and minimize the product/service failure risk. Second, the consumers feel more satisfied when they get the products/services according to their needs and becoming loyal definitely increase their direct impact on sales of the service providers.

This study aims at identifying such problem, factors related to the same and how the marketers can utilize the models and learning to predict the decision-making pattern of customers in Indian digital market. In the year of 2016-17, overall growth of online market was $19 \%$ and it is estimated that Indian e-commerce market is likely to touch USD 33 billion in 2017. Therefore, the outcomes of this study help the online service providers to understand the factors which are impacting in consumers' changing pattern and predict them well. The digital market evaluation problem also includes numerous qualitative factors measured with unclearness in data (Akhter et al., 2005; Liu and Chen, 2009; Packard and Wooten, 2013). To deal with this problem, in this work, a combined approach based on fuzzy Delphi and fuzzy AHP is used. Fuzzy Delphi method is used to finalize the factors. Fuzzy AHP helps in computing the priority weights of the finalized factors and proposing a hierarchy model for predicting the consumer decision making changing pattern $(\mathrm{Wu}, 2012)$. Fuzzy theory is used to capture the vagueness and ambiguity of human judgments (Wu, 2012; Zadeh, 1965). In 
addition, this work ultimately seeks to propose a structural hierarchy model of factors of consumer's changing pattern to help decision makers and marketers in e-commerce business success.

The organization of the remaining sections of the paper is as follows: Section 2 presents the review of literature on consumer decision making and digital market. In Section 3, research methods are mentioned. Research framework is provided in Section 4. Section 5 includes the analysis of results. Implications of the outcomes are included in Section 6. Finally, conclusion and directions of future research are mentioned in Section 7.

\section{Literature review}

This section presents the literature related to customer decision making changing pattern, and use of fuzzy based research methods in digital market.

\subsection{Customer decision making: Changing pattern}

Customer decision making on digital platforms are rapidly changing due to the fast transforming information technology. There has been couple of studies on this area stating about the factors influencing decision making of customers on online platforms (Bilgihan, 2016; Khare, 2012; Filieri, 2015; Yang et al., 2017). These studies are necessary for the marketer who appropriately utilizes the findings to formulate a proper marketing mix (Boland et al., 2012). The existing research on identifying customer decision making pattern is grounded by various models (Chou et al., 2010; Hung et al., 2012). As the use of footstep graph and navigation patterns with the integration of BPN (Back propagation network) model helps in identifying customer's behaviour in e-commerce website with more accuracy (Chou et al., 2010). Further, due to increased usage of internet, customer perception on their past purchase plays an important role in deciding their present purchasing behaviour (Boland et al., 2012; Hernández et al., 2010). Digital markets which include mostly e-commerce businesses uses the implications of the customer purchasing decision based on their past experiences. Besides, online customer reviews help the marketers in influencing their customer decision making intention (Lee et al., 2011). Customers are more inclined towards making a unique product purchase with small effects of peer communication influenced their attitudes on purchasing (Wang et al., 2012). Capabilities of customers are getting enhanced with the advancement in electronic environment (Punj, 2013). Decision making of customers depends on several factors, like what are the product features at e-commerce websites, how convenient is the navigation of the website, how much information about the product is being 
available in digital markets and how much savings can be made when compared offline and online purchasing (Chaparro-Peláez et al., 2016; Kukar-Kinney et al., 2016; Lu and Gursoy, 2015; Yeo et al., 2017) Customers mostly decide upon that product which helps in maximizing their utility and minimizing their risks.

From previous literature, decision making models have a great scope in predicting customer buying behaviour (Kumar and Dash, 2017). Digital technology becoming highly penetrating resulting in competitive pricing and marketing in the digital market place. This is the reason that studies and results supporting the customer decision making pattern are highly desirable for different e-commerce players. Therefore, it has become highly necessary to identify and retain the profitable customer to maintain higher profit margins (Auh et al., 2008; Lau et al., 2016). Similarly, the performance and quality of websites are significant for the creation of a model in analysing the performances of the online service providers, and hence figuring out the managerial activities required for bringing about an ideal web based marketing (Tsai et al., 2011). Information provided on websites and the quality of service are the most important factors customers look into while making purchase from digital market (Akhter et al., 2005). Although there are numerous studies determining the factors that affect the customer decision making process (Akhter et al., 2005; Khare, 2012), there exists a gap in determining the evolving pattern of customer decision making process. After doing extensive literature, thirty-five factors related to changing pattern of consumer decision in digital market are identified. All factors are listed in Table 1 with support references. 
Table 1. Factors for changing pattern of consumer decision making

\begin{tabular}{|c|c|}
\hline Factors & Support references \\
\hline 1. The trendiest products & Akhter et al. (2005); Ashman et al. (2015); Khare (2012); Yang et al. (2017) \\
\hline 4. Customize products & $\begin{array}{l}\text { Chaparro-Peláez et al. (2016); Grosso et al. (2017); Jiang et al. (2015); Samuel et al. } \\
\text { (2015); Xu et al. (2017) }\end{array}$ \\
\hline 5. Up-to-date products & Baldus et al. (2015); Khare (2012); Lissitsa and Kol (2016); Wang et al. (2008) \\
\hline 7. Innovative style of products & Prakash et al. (2018); Shams et al. (2015); Zhu and Zhang (2010) \\
\hline 8. Branded products: a sense of prestige & Chae and Ko (2016); Jiang et al. (2015); Liu et al. (2013); Samuel et al. (2015) \\
\hline 9. Best quality products & $\begin{array}{l}\text { Clemes et al. (2014); Müller and Diels (2016); Pappas et al. (2016); Pappas et al. } \\
\text { (2017); Prakash et al. (2018); Yang et al. (2017) }\end{array}$ \\
\hline 10. Care of online purchase brands & $\begin{array}{l}\text { Bilgihan (2016); Kim et al. (2010); Kumar and Dash (2015); MacInnis and Folkes } \\
\text { (2017); Prakash et al. (2018); Yeo et al. (2017) }\end{array}$ \\
\hline 13. $24 \times 7$ online shopping facility & Gupta et al. (2017); Kumar and Dash (2015) \\
\hline 14. Save time & Akhter et al. (2005); Gupta et al. (2017); Khare (2012); Ye et al. (2011) \\
\hline 15. Error-free transactions & Sahney (2015); Wang and Wang (2010); \\
\hline 16. Required stocks & Bilgihan (2016); Sahney (2015) \\
\hline 17. Return policy & Harris (2010); Kacen et al. (2013); Li et al. (2013) \\
\hline 18. Global recognition & Chiu et al. (2013); Hung et al. (2012) \\
\hline 19. Centralized distributed reputation systems & Havakhor et al. (2018); Hung et al. (2012); Morid and Shajari (2012) \\
\hline 20. Loyal to certain online stores and brands & Eisingerich et al. (2015); Grosso et al. (2017); Jiang et al. (2015); Xu et al. (2017) \\
\hline 21. Online reputation & Gupta et al. (2017); Hung et al. (2012); Lee et al. (2011); Silva et al. (2008) \\
\hline
\end{tabular}




\begin{tabular}{|l|l|}
\hline 22. Confusion availability of many online brands & $\begin{array}{l}\text { Bhargave et al. (2016); Darley et al. (2010); Lu and Gursoy (2015); Lu et al. (2016); } \\
\text { Röllecke et al. (2018); Tjiptono et al. (2014) }\end{array}$ \\
\hline 23. Excessive information & $\begin{array}{l}\text { Bhargave et al. (2016); Darley et al. (2010); Kukar-Kinney et al. (2016); Lu and Gursoy } \\
\text { (2015) }\end{array}$ \\
\hline 24. Confusion availability of many online stores & Bhargave et al. (2016); Chen et al. (2015); Darley et al. (2010); Lu et al. (2016) \\
\hline 25. Price comparison & $\begin{array}{l}\text { Bilgihan (2016); Bodu et al. (2015); Kim et al. (2012); Kukar-Kinney et al. (2016); Lu } \\
\text { and Gursoy (2015) }\end{array}$ \\
\hline 26. Can change my regular online brands & $\begin{array}{l}\text { Bupta et al. (2017); Hung et al. (2012); Röllecke et al. (2018) } \\
\text { (2012); Kukar-Kinney et al. (2016); Lu and Gursoy (2015); Yeh et al. (2016); }\end{array}$ \\
\hline 27. Value for money & $\begin{array}{l}\text { Bilgihan (2016); Bodu et al. (2015); Kim et al. (2012); Kukar-Kinney et al. (2016); } \\
\text { Lambert and Desmond (2013); Yeh et al. (2016) }\end{array}$ \\
\hline 28. Price sensitivity & $\begin{array}{l}\text { Heitz-Spahn (2013); Kim et al. (2012); Kukar-Kinney et al. (2016); Wallace et al. } \\
\text { (2012); Yeh et al. (2016) }\end{array}$ \\
\hline 29. Likeness of brand by others & $\begin{array}{l}\text { Jiang et al. (2015); Kukar-Kinney et al. (2016); Röllecke et al. (2018); Samuel et al. } \\
\text { (2015); Wallace et al. (2012) }\end{array}$ \\
\hline 30. Friends influence & Du et al. (2010); Essoussi and Linton (2010); Kim et al. (2010) \\
\hline 31. Product involvement in society welfare & $\begin{array}{l}\text { Bodu et al. (2015); Gupta et al. (2017); Kumar and Dash (2017); Lambert and } \\
\text { Desmond (2013); Yeh et al. (2016) }\end{array}$ \\
\hline 32. Stick usually buy brand and try that not sure & $\begin{array}{l}\text { Du et al. (2010); Kim et al. (2010); Kukar-Kinney et al. (2016); Kumar and Dash } \\
\text { (2015) }\end{array}$ \\
\hline 33. Company involvement in society welfare & $\begin{array}{l}\text { Essoussi and Linton (2010); Kim et al. (2010); Kumar and Dash (2015); Wallace et al. } \\
\text { (2012) } \\
\text { Gupta et al. (2017); Khare (2012); Kim et al. (2010); Röllecke et al. (2018) }\end{array}$ \\
\hline 34. Pay extra for products that give back to society & \\
\hline 35. Feel more insure in online purchasing & (2016); \\
\hline
\end{tabular}




\subsection{Use of fuzzy based research methods in digital market}

Online consumers feel confused when there are alternative and variety products and services available in the digital platform. In online market, there can be no concession and bargaining as there is no physical interaction between seller and buyer (Kumar and Dash, 2015). Therefore, digital market problems as fuzzy MCDM problems by the reason they include bountiful qualitative factor assessed by using linguistic terms and vague data (Akhter et al., 2005; Liu and Chen, 2009). Such type of complications can be handled with the help of Multiple Attribute Decision Making (MADM) (Gandhi et al., 2016). The MADM is one of the established methods that deal with problems involving multiple objectives (Kumar et al., 2017). Nevertheless, these methods are incapable to capture the vagueness and ambiguity of human judgments, and thus, fuzzy theory is used applied. Table 2 summarizes the studies where the researchers used different research methods blended with fuzzy theory in digital market; however combined fuzzy based Delphi and AHP techniques have a very limited use. In this sense, we preferred to employ combined fuzzy based Delphi and AHP techniques in the study.

Table 2. Applications of fuzzy based research methods in digital market

\begin{tabular}{|l|l|l|}
\hline Authors & Application area & Used methods \\
\hline Lee and Ahn (2009) & $\begin{array}{l}\text { Proposed B-to-C strategy e-commerce web } \\
\text { system }\end{array}$ & Fuzzy Cognitive Map \\
\hline Liu and Chen (2009) & Recruiting website and their prioritization & Fuzzy AHP \\
\hline Mohanty and Passi (2010) & System which based to buyers' feedbacks & Fuzzy Approach \\
\hline $\begin{array}{l}\text { Kabir and Akhtar Hasin } \\
\text { (2011) }\end{array}$ & $\begin{array}{l}\text { Identification of success factors of mobile e- } \\
\text { commerce }\end{array}$ & Fuzzy AHP \\
\hline Zandi and Tavana (2011) & $\begin{array}{l}\text { Develop the e-CRM framework in agile } \\
\text { manufacturing }\end{array}$ & Fuzzy QFD \\
\hline $\begin{array}{l}\text { Büyüközkan and Çifçi } \\
\text { (2012) }\end{array}$ & e-service quality in healthcare & $\begin{array}{l}\text { Fuzzy AHP and Fuzzy } \\
\text { TOPSIS }\end{array}$ \\
\hline Tavana et al. (2013) & Process of selection social media platform & Fuzzy ANP \\
\hline Wang (2013) & $\begin{array}{l}\text { Customer satisfaction and product } \\
\text { configuration }\end{array}$ & Fuzzy Kano \\
\hline Naili et al. (2015) & E-Commerce issues & Fuzzy MCDM \\
\hline Şengül and Eren (2015) & E-market place & Fuzzy AHP -TOPSIS \\
\hline Joshi and Alur (2015) & Enhancing buyer and seller preferences \\
\hline $\begin{array}{l}\text { Kaltenrieder et al. } \\
\text { (2015) }\end{array}$ & $\begin{array}{l}\text { To improve digital marketing management } \\
\text { endeavours }\end{array}$ & Fuzzy ANP \\
\hline Kang et al. (2016) & Evaluation of e-commerce websites & Fuzzy TOPSIS \\
\hline $\begin{array}{l}\text { Sohaib and Naderpour } \\
\text { (2017) }\end{array}$ & cloud computing and e-commerce & Fuzzy TOPSIS \\
\hline Chiang (2017) & Discovering customer value for marketing & Fuzzy MCDM \\
\hline
\end{tabular}




\subsection{Research gaps}

The literature shows various studies are available related to the prediction of factor influencing online consumers' behaviour (Bhargave et al., 2016; Darley et al., 2010; Lu and Gursoy, 2015; Lu et al., 2016; Röllecke et al., 2018; Tjiptono et al., 2014) etc. But, a very little discussion is available where the researchers talked about their changing pattern especially in the context of Indian digital market. Notably, round 14\% Indians do shop online, and this rate is increasing very fast and showing a huge opportunity (Baldus et al., 2015; Khare, 2012; Lissitsa and Kol, 2016). Therefore, this work is an attempt to fill this literature gap and to understand the changing pattern of consumers. After doing literature review extensively, we came to know that a very few studies are available where fuzzy theory is used in the context of digital market. Even the digital market evaluation problem also includes numerous qualitative factors measured with unclearness in data (Akhter et al., 2005; Liu and Chen, 2009; Packard and Wooten, 2013). A combined approach of fuzzy Delphi and AHP is not employed to understand their changing pattern. This provides further opportunity for future researchers in this area of research.

\section{Research methods}

This work uses fuzzy Delphi and fuzzy AHP as the research methods. Fuzzy Delphi method is useful in finalizing the factors related to changing pattern of consumer decision making (Ishikawa et al., 1993). Fuzzy AHP helps in finding the priority weights of factors and proposing a structural hierarchy model of the finalized factors. The reason for combining the fuzzy Delphi and fuzzy AHP methods are given as below:

(i) The combined fuzzy based Delphi and AHP tool is a systematic method of decision making, which offers logical means to list the changing pattern factors of consumer perspective.

(ii) The combined fuzzy based Delphi - AHP allows knowing the most significant changing pattern factors in managing the of consumer preferences in decision making. A brief explanation of these methods along with fuzzy theory is given as follows:

\subsection{Fuzzy set theory}

Zadeh (1965) developed fuzzy set theory, which formulates inductive reasoning with the help of human actions/reactions and consciousness. This mathematical theory deals with the ambiguity of natural language, which abducts the human communications, actions, emotions, perceptions and thoughts. Human behaviour is very subjective in nature, unlike the binary 
computer language that creates ambiguity of the information and can be dealt with fuzzy logics (Dağdeviren and Yüksel, 2008). Fuzzy theory helps in easing the interactions of humans with machines (Zadeh, 1965). Generally triangular fuzzy numbers (TFNs) are used for analysing such fuzziness. These TFNs can be depicted as:

$\mu_{\widetilde{N}}(x)=\left\{\begin{array}{lr}0, & x<l, \\ (x-a) /(b-a), & a \leq x \leq b, \\ (c-x) /(c-b), & m \leq x \leq r, \\ 0, & x>r,\end{array}\right.$

The graphical depiction of TFNs is portrayed in Fig.1.

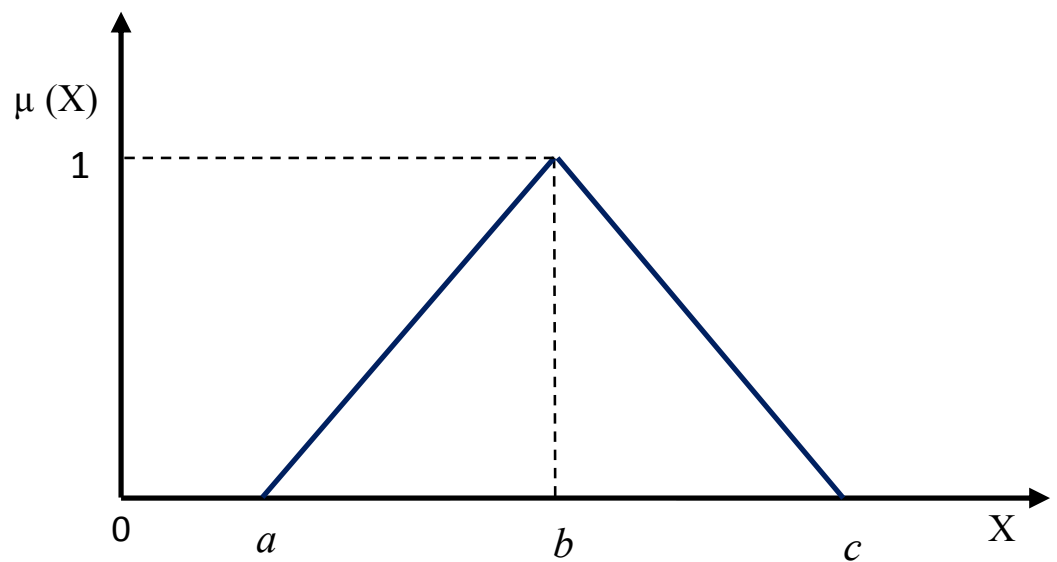

Fig. 1 Graphical depiction of TFNs

Large number of factors from human emotions makes the analysing of the logic more and more complex. Therefore, this work integrates fuzzy theory with Delphi and AHP to evaluate the problem of changing pattern of consumer decision making. A brief overview of fuzzy Delphi and fuzzy AHP is given as below:

\subsection{Fuzzy Delphi method}

Fuzzy Delphi is a qualitative method and preferred over the conventional Delphi method (Kumar et al., 2017). It incurs comparatively lower costs and time by reducing the number of surveys and increasing the questionnaire recovery rate (Ishikawa et al., 1993). Taking the completeness and consistence of experts' opinions, fuzzy Delphi method avoids misinterpreting the originality (Bouzon et al., 2016). Fuzzy Delphi brings ideas that is a result of collective decision making (Linstone et al, 2002). It is a predictive tool that takes into account expert's outlooks and opinions. To ensure anonymity i.e. being influenced or views getting objectified, the experts are kept away from each other. Regular feedback mechanism ensures revamping of the opinions. The feedback helps convergence of expert opinions. To integrate expert judgment in the process aimed at identifying the evaluation factor, fuzzy 
Delphi technique using triangular fuzzy is employed. The procedure of applying fuzzy Delphi is described as follows:

In the first step, the factors are evaluated by the experts using linguistic scale in the questionnaire. Eq.1. represents the fuzzy number of opinions from experts.

$$
\tilde{X}_{n}=\left(a_{i j}, b_{i j,}, c_{i j}\right)
$$

Where $\tilde{X}_{k}$ subject to the individual expert opinion. In the second step, the fuzzy number of opinions from the expert i.e. $a_{i j}, b_{i j}, c_{i j}$ are calculated by using Eq. (2)-Eq. (4)

$$
\begin{aligned}
a_{i j} & =\operatorname{Min}\left(a_{i j}\right), i=1 \text { to } n \text { and } j=1 \text { to } m \\
\mathrm{~b}_{i j} & =\left(\prod_{i=1, j=1}^{n, m} b_{i j}\right) 1 / \mathrm{n}, i=1 \text { to } n \text { and } j=1 \text { to } m \\
\mathrm{c}_{i j} & =\operatorname{Max}\left(c_{i j}\right), i=1 \text { to } n \text { and } j=1 \text { to } m
\end{aligned}
$$

Where $k$ is the number of experts from whom feedback, and opinions are collected, and $\mathrm{n}$ and $m$ are the number of factors and sub-factors affecting the changing pattern of customer decision making.

In the third step the fuzzy spread and mean (Mardani et al., 2016; Wu and Zhang, 2004) methods is used to get crisp of $j$ by using Eq. (5).

$$
S_{j}=\left(\frac{a_{i j}+b_{i j}+c_{i j}}{3}\right)
$$

This crisp value allows understanding the significance of the factors for changing pattern of customer decision making in the digital market in this research.

\subsection{Fuzzy AHP}

The AHP method is developed by Saaty (1980) for finding the weight of concern of factor and sub-factor of the system (Dağdeviren and Yüksel, 2008; Kuamr and Dash, 2014, Vidal et al., 2011; Veisi et al., 2016). With help of this method, the priority of the associated factors can be calculated easily however this method is not able to handle the certainty and ambiguity of human judgment (Chang 1992; Mangla et al., 2016). To deal with such situations, fuzzy AHP method was introduced (Chang 1992; Govindan et al., 2017). The step wise process of fuzzy AHP (Wang et al., 2007) is as follows:

Step 1: The factors to changing pattern of consumer decision making are listed and goal to prioritize these factors is decided.

Step 2: Given an object set:

$$
\mathrm{X}=\left\{x_{1}, x_{2}, \ldots, x_{n}\right\}
$$


and a goal set:

$$
\mathrm{G}=\left\{g_{1}, g_{2}, \ldots, g_{n}\right\}
$$

Where object and subsequent goal are considered for customer decision making changing pattern analysis, for which the analysis values representing the TFNs are represented as:

$$
M_{k_{i}}^{\mathrm{j}}, M_{k_{i}}^{\mathrm{j}}, \ldots ., M_{k_{i}}^{j}, i=1 \text { to } n \& j=1 \text { to } m
$$

With respect to the $i^{\text {th }}$ object, the value of fuzzy synthetic extent using Chang Extent analysis method is given as:

$$
S_{i}=\sum_{j=1}^{m} M_{k_{i}}^{j} \otimes\left[\sum_{i=1}^{n} \sum_{j=1}^{m} M_{k_{i}}^{j}\right]^{-1}
$$

To obtain $\sum_{j=1}^{m} M_{k_{i}}^{j}$, fuzzy addition operation needs to be performed for $m$ as:

$$
\sum_{j=1}^{m} M_{k_{i}}^{j}=\left(\sum_{j=1}^{m} a_{j}, \sum_{j=1}^{m} b_{j}, \sum_{j=1}^{m} c_{j}\right)
$$

and to obtain $\left[\sum_{i=1}^{n} \sum_{j=1}^{m} M_{k_{i}}^{j}\right]^{-1}$, fuzzy addition operation need to be performed for $M_{k_{i}}^{j}(j=$ 1 to $m$ ) values such that:

$$
\sum_{i=1}^{n} \sum_{j=1}^{m} M_{k_{i}}^{j}=\left(\sum_{i=1}^{n} a_{i}, \sum_{i=1}^{n} b_{i}, \sum_{i=1}^{n} c_{i}\right)
$$

then inverse of the identified vector is computed by substituting the values in Eq.(11) such that

$$
\left[\sum_{i=1}^{n} \sum_{j=1}^{m} M_{k_{i}}^{j}\right]^{-1}=\left(\frac{1}{\sum_{i=1}^{n} c_{i}}, \frac{1}{\sum_{i=1}^{n} b_{j}}, \frac{1}{\sum_{i=1}^{n} a_{j}}\right)
$$

Step 3: $M_{2} \geq M_{1}$ is defined as:

$$
P_{r}\left(M_{2} \geq M_{1}\right)=\sup _{y \geq x}\left[\min \left(\mu_{M_{1}}(p), \mu_{M_{2}}(q)\right)\right]
$$

When a pair $(p, q)$ exists such that $q \geq \mathrm{p}$ and $\mu_{M_{1}}(p)=\mu_{M_{2}}(q)$, then we have $P_{r}\left(M_{2} \geq\right.$ $\left.M_{1}\right)=1$. Since $M_{1}=\left(a_{1}, b_{1}, c_{1}\right)$ and $M_{2}=\left(a_{2}, b_{2}, c_{2}\right)$ are convex fuzzy numbers then

$$
P_{r}\left(M_{2} \geq M_{1}\right)=\operatorname{hgt}\left(M_{1} \cap M_{2}\right)=\mu_{M_{2}}\left(C_{P}\right)=\left\{\begin{array}{l}
1, \text { if } b_{2} \geq b_{1} \\
0 \text { if } a_{2} \geq c_{2} \\
\frac{a_{1}-c_{2}}{\left(b_{2}-c_{2}\right)-\left(b_{1}-a_{1}\right)}, \text { Otherwise }
\end{array}\right.
$$

Where $C_{P}$ is the crossover point's abscissa of $M_{1}$ and $M_{2}$.

Step 4: The degree of possibility for a convex fuzzy number to be greater than $f$ convex fuzzy numbers $M_{i}(i=1,2, \ldots k)$ can be defined by:

$$
P_{r}\left(M \geq M_{1}, M_{2}, \ldots . ., M_{f}\right)=P_{r}\left[\left(M \geq M_{1}\right) \text { and }\left(M \geq M_{2}\right)\right. \text { and }
$$




$$
\left.\left(M \geq M_{f}\right)\right]=\min P_{r}\left(M \geq M_{i}\right)=1,2,3, \ldots, f
$$

Assume that:

$$
C_{P}^{l}\left(A_{i}\right)=\min P_{r}\left(S_{i} \geq S_{f}\right)
$$

For $f=1,2, \ldots, n ; f \neq i$. Then the weight vector is obtained as follows:

$$
W_{v}^{a}=\left(C_{P}^{a}\left(A_{1}\right), C_{P}^{a}\left(A_{2}\right), \ldots, C_{P}^{a}\left(A_{n}\right)\right)^{T}
$$

Where $A_{i}(i=1,2, \ldots, n)$ are $n$ elements.

Step 5: After normalization, the normalized weight vectors are:

$$
W_{v}=\left(C_{P}\left(A_{1}\right), C_{P}\left(A_{2}\right), \ldots, C_{P}^{a}\left(A_{n}\right)\right)^{T}
$$

Where, $W_{v}$ is not a fuzzy number? The estimation procedure framework for fuzzy Delphi and AHP is given in Fig. 1

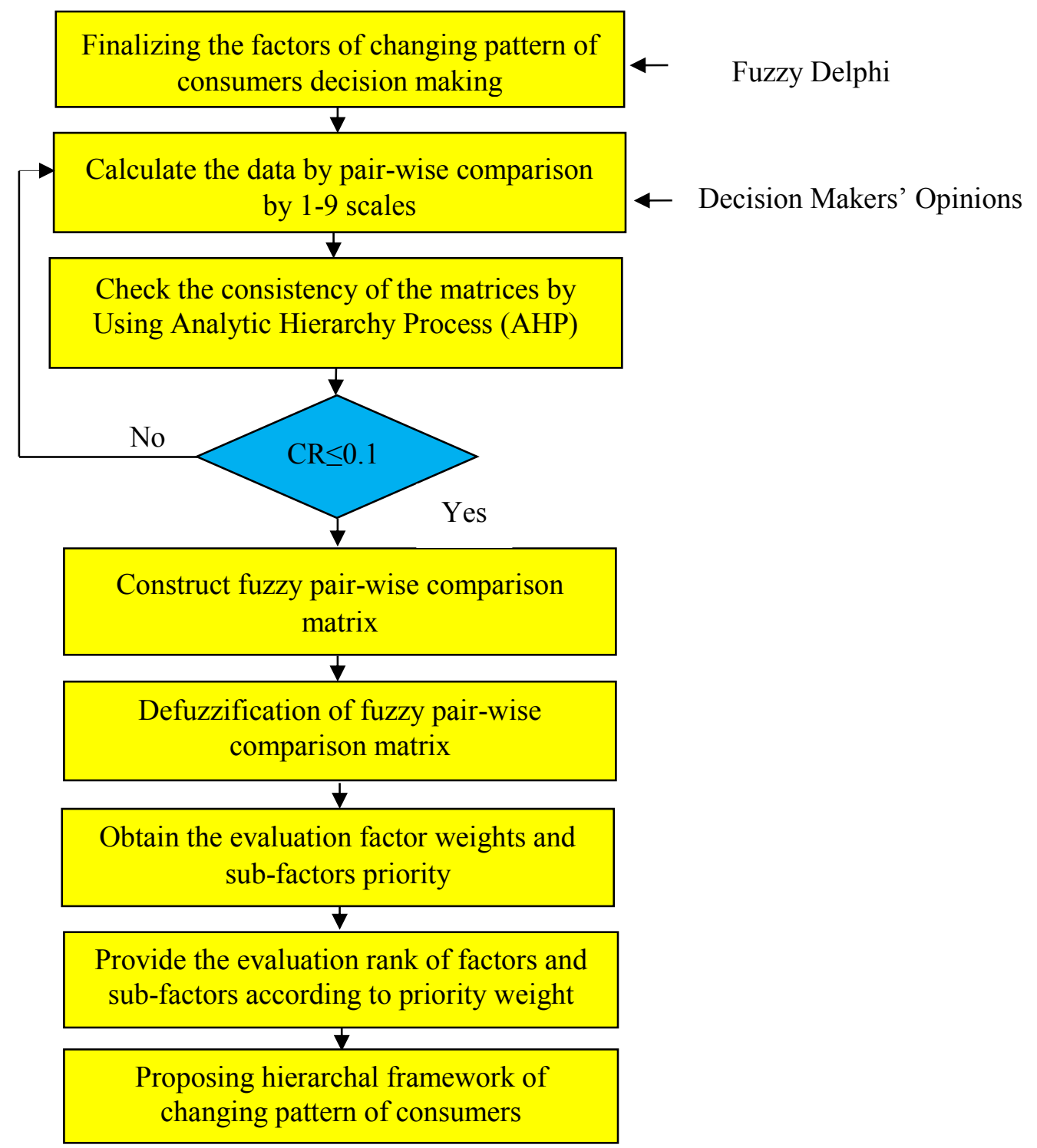

Fig.2 Estimation procedures of fuzzy Delphi and Fuzzy AHP 


\section{Research Framework}

The proposed research framework of changing pattern of consumer is based on combined approach of fuzzy Delphi and fuzzy AHP methods, consists of two phased study as mentioned in Fig. 3 consists of following sub-sections:

\subsection{Phase 1: Identification and validation of factors for changing pattern of consumer decision making in digital market}

In the first phase of the study, the qualitative analysis method, which includes the extensive literature review and fuzzy Delphi for identification and finalization of factors related to changing pattern of consumer decision making in digital market, is conducted.

\subsection{Phase 2: Compute the priority weights of finalized factors and propose a structural \\ hierarchy model}

After finalizing the factors for the problem, fuzzy AHP method is utilized in this phase. Fuzzy AHP allows determining the priority weight of each factor and proposes a hierarchal model through expert's feedback.

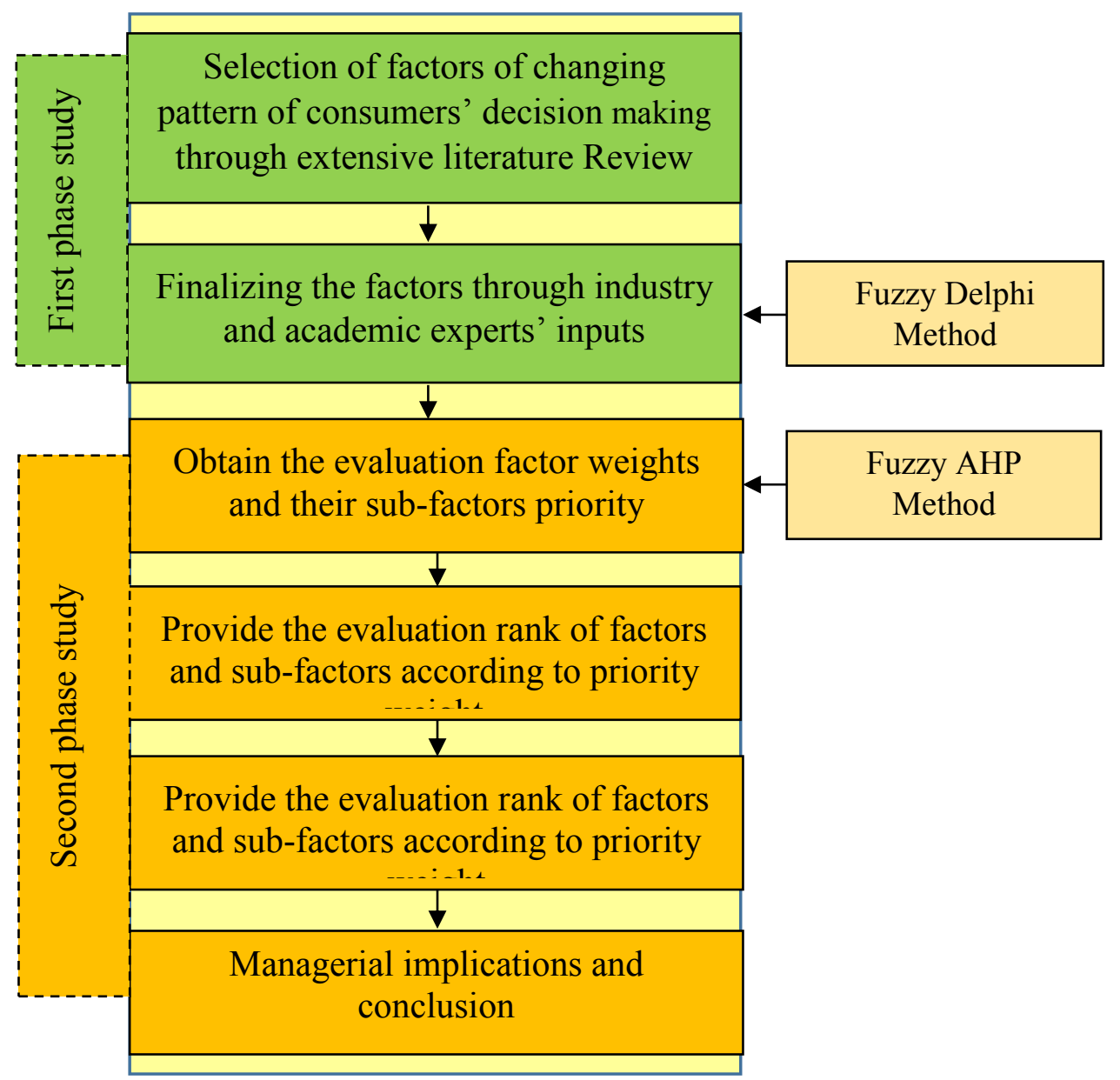

Fig.3. Flow chart of the study 


\section{Data analysis and results}

The analysis of the study has been made as per the proposed research framework as depicted in Fig.2.

\subsection{Phase 1: Identification and validation of factors for changing pattern of consumer decision making in digital market}

Through literature review, thirty-five factors are extracted, which are related to the changing pattern of consumer making in digital market. To deal with the vagueness of information, a Delphi method with fuzzy theory has been used as mentioned in Section 3.1.

A questionnaire (a draft attached in Appendix A1) prepared on the basis of triangular fuzzy numbers (TFN) scales is presented in Table 3.

Table 3. Scales for measurement

\begin{tabular}{|c|c|c|c|c|c|c|c|c|c|c|c|c|c|c|c|}
\hline $\begin{array}{c}\text { Linguistic } \\
\text { Scales }\end{array}$ & \multicolumn{3}{|c|}{$\begin{array}{l}\text { Extremely } \\
\text { Important }\end{array}$} & \multicolumn{3}{|c|}{ Important } & \multicolumn{3}{|c|}{ Normal } & \multicolumn{3}{|c|}{ Unimportant } & \multicolumn{3}{|c|}{$\begin{array}{c}\text { Extremely } \\
\text { Unimportant }\end{array}$} \\
\hline TFN & 0.7 & 0.9 & 0.9 & 0.5 & 0.7 & 0.9 & 0.3 & 0.5 & 0.7 & 0.1 & 0.3 & 0.5 & 0.1 & 0.1 & 0.3 \\
\hline
\end{tabular}

The data for this study has been collected from industry experts who have a minimum of ten years of industry experience and from the academics who are at the position of professor/associate professor. In this work, there were twenty experts in the decision group for collecting the data for fuzzy Delphi process and which is quite acceptable (Anderson et al., 2001; Ma et al., 2011; Bouzon et al., 2016). Out of twenty, twelve respondents from ecommerce are having more ten years of experience and eight academics are at the position of professor/associate professor. The importance of the factors is measured using Equations (15) and Table 4 shows the results of Fuzzy Delphi method (FDM) analysis. Discussion with experts and taking help from previous studies, for selecting and rejection of particular factor, the threshold value $r=0.60$ is set. The threshold value shows the importance of factors, those factors have threshold value $>0.60$ are selected $(S)$ otherwise rejected $(\mathrm{R})$.

Table 4. FDM analysis for finalizing the factors

\begin{tabular}{|c|c|c|c|}
\hline Factor & Fuzzy Weight & Defuzzification & $\mathbf{S} / \mathbf{R}$ \\
\hline 1. The trendiest products & $(0.70,0.97,1.00)$ & 0.89 & $\mathrm{~S}$ \\
\hline 2. Customize products & $(0.30,0.64,1.00)$ & 0.65 & $\mathrm{~S}$ \\
\hline 3. Innovative style of products & $(0.30,0.74,1.00)$ & 0.68 & $\mathrm{~S}$ \\
\hline 4. Up-to-date products & $(0.30,0.70,1.00)$ & 0.67 & $\mathrm{~S}$ \\
\hline 5. Attractive features of products & $(0.30,0.69,1.00)$ & 0.66 & $\mathrm{~S}$ \\
\hline 6. Varieties of products & $(0.50,0.93,1.00)$ & 0.81 & $\mathrm{~S}$ \\
\hline 7. Standard and expectations for a product & $(0.20,0.50,1.00)$ & 0.57 & $\mathrm{R}$ \\
\hline 8. Branded products: a sense of prestige & $(0.50,0.91,1.00)$ & 0.80 & $\mathrm{~S}$ \\
\hline 9. Best quality products & $(0.30,0.68,1.00)$ & 0.66 & $\mathrm{~S}$ \\
\hline 10. Thought or care of online purchase brands & $(0.30,0.76,1.00)$ & 0.69 & $\mathrm{~S}$ \\
\hline 11. Brand favoritism & $(0.20,0.54,1.00)$ & 0.58 & $\mathrm{R}$ \\
\hline 12. Brand loyalty & $(0.30,0.90,1.00)$ & 0.73 & $\mathrm{~S}$ \\
\hline
\end{tabular}




\begin{tabular}{|l|l|l|l|}
\hline 13. 24×7 online shopping facility & $(0.50,0.88,1.00)$ & 0.79 & $\mathrm{~S}$ \\
\hline 14. Save time & $(0.50,0.87,1.00)$ & 0.79 & $\mathrm{~S}$ \\
\hline 15. Error-free transactions & $(0.30,0.76,1.00)$ & 0.69 & $\mathrm{~S}$ \\
\hline 16. Required stocks & $(0.30,0.74,1.00)$ & 0.68 & $\mathrm{~S}$ \\
\hline 17. Return policy & $(0.30,0.68,1.00)$ & 0.66 & $\mathrm{~S}$ \\
\hline 18. Global recognition & $(0.30,0.68,1.00)$ & 0.66 & $\mathrm{~S}$ \\
\hline 19. Centralized distributed reputation systems & $(0.30,0.72,1.00)$ & 0.67 & $\mathrm{~S}$ \\
\hline 20. Loyal to certain online stores and brands & $(0.30,0.40,1.00)$ & 0.57 & $\mathrm{R}$ \\
\hline 21. Online reputation & $(0.50,0.94,1.00)$ & 0.81 & $\mathrm{~S}$ \\
\hline 22. Confusion availability of many brands & $(0.50,0.88,1.00)$ & 0.79 & $\mathrm{~S}$ \\
\hline 23. Excessive information & $(0.10,0.72,1.00)$ & 0.61 & $\mathrm{~S}$ \\
\hline 24. Confusion availability of many online stores & $(0.30,0.71,1.00)$ & 0.67 & $\mathrm{~S}$ \\
\hline 25. Price comparison & $(0.30,0.68,1.00)$ & 0.66 & $\mathrm{~S}$ \\
\hline 26. Can change my regular online buying brands & $(0.20,0.40,1.00)$ & 0.53 & $\mathrm{R}$ \\
\hline 27. Value for money & $(0.30,0.82,1.00)$ & 0.71 & $\mathrm{~S}$ \\
\hline 28. Price sensitivity & $(0.20,0.50,1.00)$ & 0.57 & $\mathrm{R}$ \\
\hline 29. Likeness of brand by others & $(0.10,0.72,1.00)$ & 0.61 & $\mathrm{~S}$ \\
\hline 30. Friends influence & $(0.30,0.86,1.00)$ & 0.72 & $\mathrm{~S}$ \\
\hline 31. Product involvement in society welfare & $(0.20,0.43,1.00)$ & 0.54 & $\mathrm{R}$ \\
\hline 32. Stick usually buy brand and try that not sure of & $(0.50,0.87,1.00)$ & 0.79 & $\mathrm{~S}$ \\
\hline 33. Company involvement in society welfare & $(0.30,0.76,1.00)$ & 0.69 & $\mathrm{~S}$ \\
\hline 34. Pay extra for products that give back to society & $(0.30,0.82,1.00)$ & 0.71 & $\mathrm{~S}$ \\
\hline 35. Feel more insure during online purchasing & $(0.10,0.42,1.00)$ & 0.51 & $\mathrm{R}$ \\
\hline
\end{tabular}

After using fuzzy Delphi, twenty-eight factors are finalized and according to their similarities, all these twenty-seven factors are classified into eight main factors; for details please refer Table 5 .

Table 5. Main factors and sub-factors for changing pattern

\begin{tabular}{|c|c|}
\hline \multicolumn{2}{|l|}{ Changing pattern factors } \\
\hline \multicolumn{2}{|l|}{ Innovative and Trendy $\left(\mathrm{F}_{1}\right)$} \\
\hline & The trendiest products $\left(\mathrm{F}_{11}\right)$ \\
\hline & Customize products $\left(\mathrm{F}_{12}\right)$ \\
\hline & Innovative style of products $\left(\mathrm{F}_{13}\right)$ \\
\hline & Up-to-date products $\left(\mathrm{F}_{14}\right)$ \\
\hline & Attractive features of products $\left(\mathrm{F}_{15}\right)$ \\
\hline & Varieties of products $\left(\mathrm{F}_{15}\right)$ \\
\hline \multicolumn{2}{|l|}{ Brand and Quality $\left(\mathrm{F}_{2}\right)$} \\
\hline & Prestige and branded products $\left(\mathrm{F}_{21}\right)$ \\
\hline & Best quality products $\left(\mathrm{F}_{22}\right)$ \\
\hline & Proper care of online brands $\left(\mathrm{F}_{23}\right)$ \\
\hline & Brand loyalty $\left(\mathrm{F}_{24}\right)$ \\
\hline \multicolumn{2}{|c|}{ Fulfilment and Time Energy $\left(\mathrm{F}_{3}\right)$} \\
\hline & $24 \times 7$ online shopping facilities $\left(\mathrm{F}_{31}\right)$ \\
\hline & Save time $\left(\mathrm{F}_{32}\right)$ \\
\hline & Error free transactions $\left(\mathrm{F}_{33}\right)$ \\
\hline & Required stocks $\left(\mathrm{F}_{34}\right)$ \\
\hline & Return policy $\left(\mathrm{F}_{35}\right)$ \\
\hline \multicolumn{2}{|l|}{ Reputation System $\left(\mathrm{F}_{4}\right)$} \\
\hline & Global recognition $\left(\mathrm{F}_{41}\right)$ \\
\hline & Centralized distribution reputation system $\left(\mathrm{F}_{42}\right)$ \\
\hline & Online reputation $\left(\mathrm{F}_{43}\right)$ \\
\hline \multicolumn{2}{|l|}{ Information Overload $\left(\mathrm{C}_{5}\right)$} \\
\hline & Confusion availability of many brands $\left(\mathrm{F}_{51}\right)$ \\
\hline & Excessive information $\left(\mathrm{F}_{52}\right)$ \\
\hline
\end{tabular}




\begin{tabular}{|c|c|}
\hline & Availability of many online store $\left(\mathrm{F}_{53}\right)$ \\
\hline \multicolumn{2}{|l|}{ Price and Value for Money $\left(\mathrm{F}_{6}\right)$} \\
\hline & Price comparison $\left(\mathrm{F}_{61}\right)$ \\
\hline & Value for money $\left(\mathrm{F}_{62}\right)$ \\
\hline \multicolumn{2}{|l|}{ Face and Risk Aversion $\left(\mathrm{F}_{7}\right)$} \\
\hline & Likeness of brand by others $\left(\mathrm{F}_{71}\right)$ \\
\hline & Friends influence $\left(\mathrm{F}_{72}\right)$ \\
\hline & Stick usually buy brand and try not sure of $\left(\mathrm{F}_{73}\right)$ \\
\hline \multicolumn{2}{|l|}{ Social Aspects $\left(\mathrm{F}_{8}\right)$} \\
\hline & Company involvement in society welfare $\left(\mathrm{F}_{81}\right)$ \\
\hline & Pay extra products that give society $\left(\mathrm{F}_{82}\right)$ \\
\hline
\end{tabular}

\subsection{Phase 2: Compute the priority weights of finalized factors and propose a structural hierarchy model}

To find the weight for each main factor and sub-factor, a pair wise questionnaire (a draft attached in Appendix A2) is designed on the basis of 1-9 scale to collect data from the experts. The experts have been contacted for data collection. For this phase, a different decision expert's group of 48 individuals is formed. It includes the customers, who is purchasing from e-commerce websites last 8-10 years, with graduation minimum qualification and spend good amount of money every month for online purchasing. The consistency of each respondents' matrix is checked by using following equations which are develop by Saaty (1980).

$$
A w=\lambda_{\max } w
$$

Eq. 20 and Eq. 21 are utilized to check the consistency in experts' opinions.

$$
\begin{aligned}
& \text { Consistency Index }(C I)=\frac{\lambda_{\max }-n}{n-1} \\
& \text { Consistency Ratio }(C R)=\frac{C I}{R I}
\end{aligned}
$$

Random Index $(R I)$ for 8 factors is 1.41 (Saaty, 1980). If $C I>0.1$, the matrix has to be revised. The consistency results respondents' matrix is given in Table 6 .

Table 6. Consistency value of respondents' matrix

\begin{tabular}{|c|l|c|l|}
\hline Matrix & Consistency Value & Matrix & Consistency Value \\
\hline $\mathrm{E}_{1}$ & $\lambda_{\max }=8.84$, C.I. $=0.12$, C.R. $=0.08$ & $\mathrm{E}_{25}$ & $\lambda_{\max }=8.89$, C.I. $=0.13$, C.R. $=0.09$ \\
\hline $\mathrm{E}_{2}$ & $\lambda_{\max }=8.81$, C.I. $=0.12$, C.R. $=0.08$ & $\mathrm{E}_{26}$ & $\lambda_{\max }=8.66$, C.I. $=0.09$, C.R. $=0.07$ \\
\hline $\mathrm{E}_{3}$ & $\lambda_{\max }=8.92$, C.I. $=0.13$, C.R. $=0.09$ & $\mathrm{E}_{27}$ & $\lambda_{\max }=8.88$, C.I. $=0.13$, C.R. $=0.09$ \\
\hline $\mathrm{E}_{4}$ & $\lambda_{\max }=8.84$, C.I. $=0.12$, C.R. $=0.08$ & $\mathrm{E}_{28}$ & $\lambda_{\max }=9.00$, C.I. $=0.14$, C.R. $=0.10$ \\
\hline $\mathrm{E}_{5}$ & $\lambda_{\max }=8.98$, C.I. $=0.12$, C.R. $=0.08$ & $\mathrm{E}_{29}$ & $\lambda_{\max }=8.78$, C.I. $=0.11$, C.R. $=0.08$ \\
\hline $\mathrm{E}_{6}$ & $\lambda_{\max }=8.70$, C.I. $=0.10$, C.R. $=0.08$ & $\mathrm{E}_{30}$ & $\lambda_{\max }=8.90$, C.I. $=0.13$, C.R. $=0.09$ \\
\hline $\mathrm{E}_{7}$ & $\lambda_{\max }=8.92$, C.I. $=0.13$, C.R. $=0.08$ & $\mathrm{E}_{31}$ & $\lambda_{\max }=8.80$, C.I. $=0.11$, C.R. $=0.08$ \\
\hline $\mathrm{E}_{8}$ & $\lambda_{\max }=8.70$, C.I. $=0.10$, C.R. $=0.07$ & $\mathrm{E}_{32}$ & $\lambda_{\max }=8.79$, C.I. $=0.14$, C.R. $=0.10$ \\
\hline $\mathrm{E}_{9}$ & $\lambda_{\max }=8.90$, C.I. $=0.13$, C.R. $=0.09$ & $\mathrm{E}_{33}$ & $\lambda_{\max }=8.95$, C.I. $=0.14$, C.R. $=0.10$ \\
\hline $\mathrm{E}_{10}$ & $\lambda_{\max }=8.84$, C.I. $=0.12$, C.R. $=0.08$ & $\mathrm{E}_{34}$ & $\lambda_{\max }=8.84$, C.I. $=0.12$, C.R. $=0.08$ \\
\hline
\end{tabular}




\begin{tabular}{|c|l|c|l|}
\hline $\mathrm{E}_{11}$ & $\lambda_{\max }=8.81$, C.I. $=0.12$, C.R. $=0.08$ & $\mathrm{E}_{35}$ & $\lambda_{\max }=8.85$, C.I. $=0.12$, C.R. $=0.09$ \\
\hline $\mathrm{E}_{12}$ & $\lambda_{\max }=9.02$, C.I. $=0.15$, C.R. $=0.10$ & $\mathrm{E}_{36}$ & $\lambda_{\max }=8.85$, C.I. $=0.12$, C.R. $=0.09$ \\
\hline $\mathrm{E}_{13}$ & $\lambda_{\max }=8.75$, C.I. $=0.11$, C.R. $=0.08$ & $\mathrm{E}_{37}$ & $\lambda_{\max }=8.83$, C.I. $=0.12$, C.R. $=0.08$ \\
\hline $\mathrm{E}_{14}$ & $\lambda_{\max }=8.88$, C.I. $=0.13$, C.R. $=0.09$ & $\mathrm{E}_{38}$ & $\lambda_{\max }=8.84$, C.I. $=0.12$, C.R. $=0.09$ \\
\hline $\mathrm{E}_{15}$ & $\lambda_{\max }=8.99$, C.I. $=0.14$, C.R. $=0.10$ & $\mathrm{E}_{39}$ & $\lambda_{\max }=8.85$, C.I. $=0.12$, C.R. $=0.08$ \\
\hline $\mathrm{E}_{16}$ & $\lambda_{\max }=8.75$, C.I. $=0.12$, C.R. $=0.08$ & $\mathrm{E}_{40}$ & $\lambda_{\max }=8.79$, C.I. $=0.14$, C.R. $=0.10$ \\
\hline $\mathrm{E}_{17}$ & $\lambda_{\max }=8.92$, C.I. $=0.13$, C.R. $=0.09$ & $\mathrm{E}_{41}$ & $\lambda_{\max }=8.93$, C.I. $=0.13$, C.R. $=0.09$ \\
\hline $\mathrm{E}_{18}$ & $\lambda_{\max }=8.66$, C.I. $=0.09$, C.R. $=0.07$ & $\mathrm{E}_{42}$ & $\lambda_{\max }=8.88$, C.I. $=0.14$, C.R. $=0.10$ \\
\hline $\mathrm{E}_{19}$ & $\lambda_{\max }=8.87$, C.I. $=0.12$, C.R. $=0.09$ & $\mathrm{E}_{43}$ & $\lambda_{\max }=8.99$, C.I. $=0.12$, C.R. $=0.08$ \\
\hline $\mathrm{E}_{20}$ & $\lambda_{\max }=8.80$, C.I. $=0.11$, C.R. $=0.08$ & $\mathrm{E}_{44}$ & $\lambda_{\max }=8.90$, C.I. $=0.13$, C.R. $=0.07$ \\
\hline $\mathrm{E}_{21}$ & $\lambda_{\max }=8.89$, C.I. $=0.14$, C.R. $=0.10$ & $\mathrm{E}_{45}$ & $\lambda_{\max }=8.87$, C.I. $=0.12$, C.R. $=0.09$ \\
\hline $\mathrm{E}_{22}$ & $\lambda_{\max }=8.94$, C.I. $=0.13$, C.R. $=0.09$ & $\mathrm{E}_{46}$ & $\lambda_{\max }=8.76$, C.I. $=0.11$, C.R. $=0.08$ \\
\hline $\mathrm{E}_{23}$ & $\lambda_{\max }=8.99$, C.I. $=0.13$, C.R. $=0.09$ & $\mathrm{E}_{47}$ & $\lambda_{\max }=8.79$, C.I. $=0.14$, C.R. $=0.10$ \\
\hline $\mathrm{E}_{24}$ & $\lambda_{\max }=8.93$, C.I. $=0.13$, C.R. $=0.09$ & $\mathrm{E}_{48}$ & $\lambda_{\max }=8.85$, C.I. $=0.12$, C.R. $=0.09$ \\
\hline
\end{tabular}

After integrating all decision makers' opinions $\left(\left(\tilde{x}_{i j}\right)=\left(a_{i j}, b_{i j}, c_{i j}\right)\right)$ through following Eq.

$l_{i j}=\min _{k}\left(c_{i j k}\right), m_{i j}=\frac{1}{k} \sum_{k=1}^{K} b_{i j k}, u_{i j}=\max _{k}\left(c_{i j k}\right)$,

where $i=1,2, \ldots, m, j=1,2, \ldots m$, and $k=1,2, \ldots, K$

The result in the form of fuzzy pairwise comparison matrix is given in Table 7 .

Table 7. Fuzzy pairwise comparison matrix

\begin{tabular}{|c|c|c|c|}
\hline $\mathbf{F}_{\mathbf{1}}$ & $\mathbf{F}_{\mathbf{2}}$ & $\mathbf{F}_{\mathbf{3}}$ & $\mathbf{F}_{\mathbf{4}}$ \\
\hline $1.00,1.00,1.00$ & $0.11,2.23,7.00$ & $0.11,3.14,9.00$ & $0.11,3.66,9.00$ \\
\hline $0.14,1.79,9.00$ & $1.00,1.00,1.00$ & $0.20,2.26,5.00$ & $0.11,2.85,7.00$ \\
\hline $0.11,1.41,9.00$ & $0.20,1.29,5.00$ & $1.00,1.00,1.00$ & $0.33,1.63,7.00$ \\
\hline $0.11,2.08,9.00$ & $0.14,1.60,9.00$ & $0.14,1.32,3.00$ & $1.00,1.00,1.00$ \\
\hline $0.14,1.20,7.00$ & $0.20,1.46,9.00$ & $0.14,1.47,7.00$ & $0.14,1.32,7.00$ \\
\hline $0.11,1.65,9.00$ & $0.11,0.67,5.00$ & $0.14,1.20,7.00$ & $0.14,1.36,5.00$ \\
\hline $0.11,1.39,9.00$ & $0.14,1.09,3.00$ & $0.11,1.00,5.00$ & $0.14,0.70,7.00$ \\
\hline $\mathbf{F}_{\mathbf{5}}$ & $\mathbf{F}_{\mathbf{6}}$ & $\mathbf{F}_{\mathbf{7}}$ & $\mathbf{F}_{\mathbf{8}}$ \\
\hline $0.14,3.07,7.00$ & $0.11,3.46,9.00$ & $0.11,4.40,9.00$ & $0.11,4.86,9.00$ \\
\hline $0.14,2.21,5.00$ & $0.11,3.66,7.00$ & $0.33,3.47,7.00$ & $0.11,3.66,9.00$ \\
\hline $0.14,2.45,7.00$ & $0.14,3.10,7.00$ & $0.20,3.73,9.00$ & $0.20,3.65,9.00$ \\
\hline $0.14,2.22,7.00$ & $0.20,2.16,7.00$ & $0.14,3.32,7.00$ & $0.11,3.48,9.00$ \\
\hline $1.00,1.00,1.00$ & $0.20,2.22,7.00$ & $0.14,2.70,7.00$ & $0.20,4.23,9.00$ \\
\hline $0.14,1.32,5.00$ & $1.00,1.00,1.00$ & $0.20,2.60,7.00$ & $0.14,2.45,7.00$ \\
\hline $0.14,0.88,7.00$ & $0.14,1.01,5.00$ & $1.00,1.00,1.00$ & $0.14,2.06,7.00$ \\
\hline
\end{tabular}

After using step 2 Eq. (8) to Eq. (10), the calculations have done as shown in Appendix A3. Then the weight vector becomes,

$$
\mathrm{W}^{\prime}=(1, .91, .87, .85, .84, .77, .72, .75)
$$

Eq. (13) is used to calculate the final weights. After the normalization of these priority weight w. r. t. main goal are calculated as normalized weights: $\mathrm{W}=(0.149,0.136,0.130,0.127$, $0.125,0.115,0.107$, and 0.112 ). Table 8 shows the priority weight of main factors along with their ranks.

Table 8. Priority weights of key factors changing pattern of consumers' decision making and their rank

\begin{tabular}{|l|l|l|}
\hline Mail factors & Priority weight & Rank \\
\hline Innovative and Trendy $\left(F_{1}\right)$ & 0.149 & 1 \\
\hline Brand and Quality $\left(F_{2}\right)$ & 0.136 & 2 \\
\hline
\end{tabular}




\begin{tabular}{|l|l|l|}
\hline Fulfilment and Time Energy $\left(\mathrm{F}_{3}\right)$ & 0.130 & 3 \\
\hline Reputation System $\left(\mathrm{F}_{4}\right)$ & 0.127 & 4 \\
\hline Information Overload $\left(\mathrm{F}_{5}\right)$ & 0.125 & 5 \\
\hline Price and Value for Money $\left(\mathrm{F}_{6}\right)$ & 0.115 & 6 \\
\hline Face and Risk Aversion $\left(\mathrm{F}_{7}\right)$ & 0.107 & 8 \\
\hline Social Aspects $\left(\mathrm{F}_{8}\right)$ & 0.112 & 7 \\
\hline
\end{tabular}

The same approach is applied for sub-factors of each key factor, and the priority weight of each sub-factor is computed along with their rank as given in Table 9. After multiplying each sub-factor's weight with its main factor weight, the global priority weight is calculated and global ranking is the overall ranking of each sub-factor. Next to this, we construct a structural hierarchy decision model of the factors and sub-factors for predicting the changing pattern of consumer decision making in digital market as shown in Fig. 3. This model has three levels (Level 1-Level 3) and developed from the opinions of the experts through fuzzy AHP technique.

Table 9. Summary of priority weight of sub-factors

\begin{tabular}{|c|c|c|c|c|c|}
\hline Factor & Sub-factor & $\begin{array}{c}\text { Local } \\
\text { priority } \\
\text { weight }\end{array}$ & $\begin{array}{c}\text { Local } \\
\text { ranking }\end{array}$ & $\begin{array}{c}\text { Global } \\
\text { priority } \\
\text { weight }\end{array}$ & $\begin{array}{c}\text { Global } \\
\text { ranking }\end{array}$ \\
\hline \multirow{6}{*}{$\begin{array}{l}\text { Innovative } \\
\text { and Trendy } \\
\left(\mathrm{F}_{1}\right)\end{array}$} & The trendiest products $\left(\mathrm{F}_{11}\right)$ & 0.134 & 5 & 0.0200 & 26 \\
\hline & Customize products $\left(\mathrm{F}_{12}\right)$ & 0.246 & 1 & 0.0367 & 12 \\
\hline & Innovative of products $\left(\mathrm{F}_{13}\right)$ & 0.143 & 3 & 0.0213 & 24 \\
\hline & Up-to-date products $\left(\mathrm{F}_{14}\right)$ & 0.225 & 2 & 0.0335 & 16 \\
\hline & Attractive features of products $\left(\mathrm{F}_{15}\right)$ & 0.137 & 4 & 0.0204 & 25 \\
\hline & Varieties of products $\left(\mathrm{F}_{16}\right)$ & 0.115 & 6 & 0.0171 & 28 \\
\hline \multirow{4}{*}{$\begin{array}{l}\text { Brand and } \\
\text { Quality } \\
\left(\mathrm{F}_{2}\right)\end{array}$} & Branded products: a sense of prestige $\left(F_{21}\right)$ & 0.218 & 3 & 0.0296 & 19 \\
\hline & Best quality products $\left(\mathrm{F}_{22}\right)$ & 0.254 & 2 & 0.0345 & 15 \\
\hline & Care of online purchase brands $\left(\mathrm{F}_{23}\right)$ & 0.170 & 4 & 0.0231 & 22 \\
\hline & Brand loyalty $\left(\mathrm{F}_{24}\right)$ & 0.358 & 1 & 0.0487 & 4 \\
\hline \multirow{5}{*}{$\begin{array}{l}\text { Fulfilment } \\
\text { and Time } \\
\text { Energy }\left(\mathrm{F}_{3}\right)\end{array}$} & $24 \times 7$ online shopping facility $\left(F_{31}\right)$ & 0.256 & 1 & 0.0333 & 17 \\
\hline & Save time $\left(\mathrm{F}_{32}\right)$ & 0.244 & 2 & 0.0317 & 18 \\
\hline & Error-free transactions $\left(\mathrm{F}_{33}\right)$ & 0.150 & 5 & 0.0195 & 27 \\
\hline & Required stocks $\left(\mathrm{F}_{34}\right)$ & 0.184 & 3 & 0.0239 & 21 \\
\hline & Return policy $\left(\mathrm{F}_{35}\right)$ & 0.166 & 4 & 0.0216 & 23 \\
\hline \multirow{3}{*}{$\begin{array}{l}\text { Reputation } \\
\text { System }\left(\mathrm{F}_{4}\right)\end{array}$} & Global recognition $\left(\mathrm{F}_{41}\right)$ & 0.328 & 2 & 0.0417 & 10 \\
\hline & Centralized distributed reputation systems $\left(\mathrm{F}_{42}\right)$ & 0.352 & 1 & 0.0447 & 8 \\
\hline & Online reputation $\left(\mathrm{F}_{43}\right)$ & 0.320 & 3 & 0.0406 & 11 \\
\hline \multirow{3}{*}{$\begin{array}{l}\text { Information } \\
\text { Overload } \\
\left(\mathrm{F}_{5}\right)\end{array}$} & Confusion availability of many brands $\left(\mathrm{F}_{51}\right)$ & 0.291 & 3 & 0.0364 & 13 \\
\hline & Excessive information $\left(\mathrm{F}_{52}\right)$ & 0.363 & 1 & 0.0455 & 7 \\
\hline & Confusion availability of many online store $\left(\mathrm{F}_{53}\right)$ & 0.354 & 2 & 0.0431 & 9 \\
\hline \multirow{2}{*}{$\begin{array}{l}\text { Price and } \\
\text { Value for } \\
\text { Money }\left(\mathrm{F}_{6}\right)\end{array}$} & Price comparison $\left(\mathrm{F}_{61}\right)$ & 0.589 & 1 & 0.0677 & 1 \\
\hline & Value for money $\left(\mathrm{F}_{62}\right)$ & 0.411 & 2 & 0.0473 & 5 \\
\hline \multirow{3}{*}{$\begin{array}{l}\text { Face and } \\
\text { Risk } \\
\text { Aversion } \\
\left(\mathrm{F}_{7}\right)\end{array}$} & Likeness of brand by others $\left(\mathrm{F}_{71}\right)$ & 0.334 & 2 & 0.0357 & 14 \\
\hline & Friends influence $\left(\mathrm{F}_{72}\right)$ & 0.441 & 1 & 0.0472 & 6 \\
\hline & Stick usually buy brand and try that not sure of $\left(\mathrm{F}_{73}\right)$ & 0.225 & 3 & 0.0241 & 2 \\
\hline \multirow{2}{*}{$\begin{array}{l}\text { Social } \\
\text { Aspects } \\
\left(\mathrm{F}_{8}\right)\end{array}$} & Company involvement in society welfare $\left(\mathrm{F}_{81}\right)$ & 0.477 & 2 & 0.0534 & 3 \\
\hline & Pay extra for products that give back to society $\left(\mathrm{F}_{82}\right)$ & 0.523 & 1 & 0.0586 & 2 \\
\hline
\end{tabular}




\section{Discussion}

The speedy development of information system infrastructure, usability of internet is increasing day by day. Because of this, the consumers are shifting themselves offline to online to buy their products and services. Due to this reason, online market is growing with rapid speed. Therefore, every business wants to capture online market but to do this proper perdition about consumer's buying behaviour and their changing pattern is very much important. The study identified eight main factors i.e. Innovative and Trendy $\left(\mathrm{F}_{1}\right)$, Brand and Quality $\left(\mathrm{F}_{2}\right)$, Fulfilment and Time Energy $\left(\mathrm{F}_{3}\right)$, Reputation System $\left(\mathrm{F}_{4}\right)$, Information Overload $\left(\mathrm{F}_{5}\right)$; Price and Value for Money $\left(\mathrm{F}_{6}\right)$; Face and Risk Aversion $\left(\mathrm{F}_{7}\right)$; Social Aspects $\left(\mathrm{F}_{8}\right)$ which are playing the important role in the changing pattern of consumer's decision making in digital market. Based on analysis, the ranks of these factors are given as $-F_{1}>F_{2}$ $>\mathrm{F}_{3}>\mathrm{F}_{4}>\mathrm{F}_{5}>\mathrm{F}_{6}>\mathrm{F}_{8}>\mathrm{F}_{7}$.

The factor 'Innovative and Trendy $\left(\mathrm{F}_{1}\right)$ ' has rank one among all factors and under this factor, the study identified the six sub-factors which are 'the trendiest products $\left(\mathrm{F}_{11}\right)$; customize products $\left(\mathrm{F}_{12}\right)$; innovative style of products $\left(\mathrm{F}_{13}\right)$; up-to-date products $\left(\mathrm{F}_{14}\right)$; attractive features of products $\left(F_{15}\right)$ and varieties of products $\left(F_{16}\right)$, and rank of these sub-factors is $F_{12}>F_{14}>$ $F_{13}>F_{15}>F_{11}>F_{16}$ with weights; 0.246, 0.225, 0.143, 0.137, 0.134, and 0.115 respectively. 'Brand and Quality $\left(\mathrm{F}_{2}\right)$ ' the second important factor, which impact on pattern of consumers' decision making in the digital market. Under this factor, the four sub-factors are: branded products: a sense of prestige $\left(\mathrm{F}_{21}\right)$; best quality products $\left(\mathrm{F}_{22}\right)$; care of online purchase brands $\left(F_{23}\right)$; brand loyalty $\left(F_{24}\right)$ are identified under this factor their rank is $F_{24}>F_{22}>F_{21}>F_{23}$ with weight $0.358,0.254,0.218$, and 0.170 .

The factor, named 'Fulfilment and Time Energy' has the rank three among all and it has five sub-factors which are $24 \times 7$ online shopping facility $\left(F_{31}\right)$, save time $\left(F_{32}\right)$; error-free transactions $\left(\mathrm{F}_{33}\right)$; required stocks $\left(\mathrm{F}_{34}\right)$; and return policy $\left(\mathrm{F}_{35}\right)$. The rank of these sub-factors; $F_{31}>F_{32}>F_{34}>F_{35}>F_{33}$ with weight $0.256,0.244,0.184,0.166$ and 0.150 . The analysis of this study shows that the factor 'Reputation System $\left(\mathrm{F}_{4}\right)$ has the rank four and under it, the sub-factors are global recognition $\left(\mathrm{F}_{41}\right)$, centralized distributed reputation system, and online reputation $\left(\mathrm{F}_{43}\right)$ are in rank two, one and three with weights $0.328,0.352$, and 0.320 . The factor 'information overload $\left(\mathrm{F}_{5}\right)$ ' has obtained fifth rank in list. Under this factor, confusion availability of many brands $\left(\mathrm{F}_{51}\right)$, excessive information $\left(\mathrm{F}_{52}\right)$ and confusion availability of many online store $\left(\mathrm{F}_{53}\right)$ are sub-factor with rank third, first and second in the list. 
Value for money (Heitz-Spahn 2013; Lu and Gursoy, 2015), price comparison (Bodu et al., 2015; Yeh et al., 2016) are important factors for consumers to take their decision, these are the sub-factors of the factor named 'Price and Value for Money $\left(\mathrm{F}_{6}\right)$, which has ranked six. These sub-factors have one and two ranks with weights 0.589 and 0.411 . The factors 'Face and Risk Aversion $\left(\mathrm{F}_{7}\right)$ and Social Aspects $\left(\mathrm{F}_{8}\right)$ have ranked seven and eight respectively in this research. There sub-factors' ranks are friends influence $\left(\mathrm{F}_{72}\right)>$ likeness of brand by others $\left(\mathrm{F}_{71}\right)>$ stick with a brand $\left(\mathrm{F}_{73}\right)$ with weights $0.411,0.334$ and 0.225 respectively and pay extra for products that give back to society $\left(\mathrm{F}_{82}\right)>$ company involvement in society welfare $\left(\mathrm{F}_{81}\right)$ with weights 0.523 and 0.477 respectively.

\section{Implications to theory and practice}

This work contributes to consumer research literature in the context of the changing pattern of consumers' decision making in the digital market. Although understanding changing pattern of consumes' decision making is very important for the service providers to provide them the best products/services according to their timely needs, a very few studies have been conducted in this area (McDonald and Wilson, 2016; Vassileva, 2017; Xiang et al., 2015). For sustainable business success, the service providers have the capability to predict consumer changing pattern properly for making the proper marketing strategy in the digital market (Ashman et al., 2015; Erevelles et al., 2016). This study has narrowed down this literature gap and developed a structural hierarchy model of factors, which are responsible for the changing pattern of consumer decision making in digital market as presented in Fig.4. The developed model helps the marketers to understand their changing pattern and identify the customers' touchpoints in the decision-making process properly and formulates further strategies to attract and retain more customers. When the changes happen in consumer preferences and buying taste, proper understanding about these changes of preference can help the service providers to make proper marketing strategy and the developed model provides the insights to the service providers to understand the consumers' changing pattern well.

The first priority factor shows that the consciousness of consumers about innovative and trendy products when they go to buy the products by online platform and this consciousness impact on their decision making (Baldus et al., 2015; Lissitsa and Kol, 2016). 


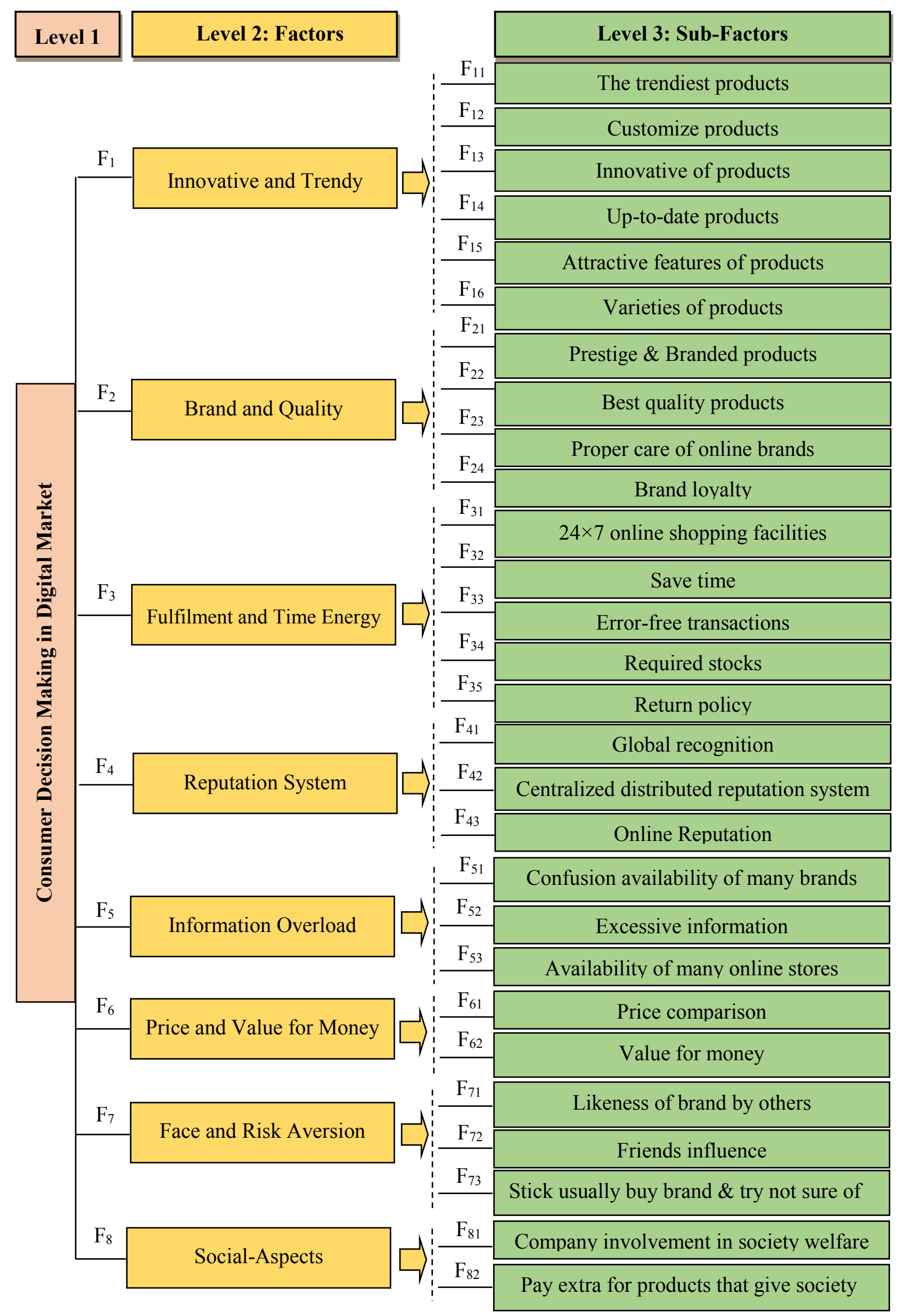

Fig.3 Structural hierarchy model of changing pattern of consumer decision making 
Therefore, the online service providers must understand their consciousness about innovative and trendy products/services and make the online marketing strategies in way so that they can provide them customize and up-to-date products, which give them feel of being innovative and trendy (Chaparro-Peláez et al., 2016; Grosso et al., 2017; Jiang et al., 2015; Xu et al., 2017).

The analysis of the study shows that the availability of different brands plays an important role of changing pattern of consumers' decision making (Chaparro-Peláez et al., 2016; Close and Kukar-Kinney, 2010; Jiang et al., 2015). This factor shows the consciousness of consumer about different brands availability in online store (Bilgihan, 2016; Mafael et al., 2016; Yeo et al., 2017) and determined if the consumers are not able to find their brand on the particular online store. This will have a significant impact on their decision making and changing pattern behaviour. Therefore, the management of the online store must think in this direction so that they can provide different brands to the consumers once they visit the online store.

The result shows the consumers are conscious about their brand loyalty and quality of brands (Chaparro-Peláez et al., 2016; Yeo et al., 2017). This understanding can help the online service providers to better understand about the consciousness of consumers about brands and quality of brands (Chaparro-Peláez et al., 2016; Jiang et al., 2015; Kumar and Dash, 2015). Therefore, the online providers must give their attention and make sure when they visit their online store they get the quality brands. The analysis shows the consumers are conscious about error free transaction, return policy, availability of stock in the online store etc. When the needs generate, the consumers want to take the decision to buy the products/services (Gupta et al., 2017; Ye et al., 2011) and then they check the required stocks available and return policy of the service providers. Therefore, considering this factor, the online service providers should think about how they can fulfil their timely needs and requirements so that they are able to increase their trust and retention (Kacen et al., 2013; Sahney, 2015; Wang and Wang, 2010).

According to analysis, online reputation of the organization is an important factor which impact on consumers' changing pattern of consumers' decision making (Hung et al., 2012). The managers of online store must think and how they can improve their online reputation so that the consumer's confidence and trust will increase on them. In digital platform, no physical interaction with consumer is possible therefore online reputation of the organization and its global recognition play very important role to gain the consumer's confidence and trust (Chiu et al., 2013; Gupta et al., 2017; Hung et al., 2012). The factors that the consumer 
is very conscious about the online reputation of the service providers include whether they have centralized distributed reputation system, their global recognition and their own online reputation. The service providers must think and focus that how they can increase their recognition globally, how they enhance their centralized distributed reputation system, and online reputation how they can increase their recognition globally, how they enhance their centralized distributed reputation system, and online reputation (Morid and Shajari, 2012; Chiu et al., 2013; Jiang et al., 2015; Grosso et al., 2017). Today, around 40\% of the world population have an Internet connection. As per the report published by Internet and Mobile Association of India (IAMAI), around 420 million Internet users are estimated in India. Therefore, it shows that any information about any product/service is spread very fast. The study shows that consumers are getting confused because of access of information which are provided by the online service providers (Bhargave et al., 2016). These days because of excessive information about products, availability of many brands and many online stores, consumers are getting confused and they are not able to choose their products/brands (Darley et al., 2010; Lu and Gursoy, 2015; Bhargave et al., 2016). To avoid this confusing situation of consumer, the service providers must think on it and give proper attention.

Before buying any product, the consumer does the price comparison and try to understand the value for the money for the same (Lu and Gursoy, 2015). This factor plays an important role to understand the price sensitivity of the consumers (Kim et al., 2012; Lambert and Desmond, 2013). The service providers must think how they can provide the better alternative options so that probability of changing can reduce. These factors show the consciousness of consumers about risk involved in digital market platform and their consciousness about society. When the consumers will go buy any product online, they generally want to share their personal information and do not want any risk involved in it (Kim et al., 2010; Khare, 2012; Gupta et al., 2017). To avoid this, the online service provider must take some corrective steps so that their trust and confidence can increase (Khare, 2012; Gupta et al., 2017). The social factor related to the social consciousness of consumers can be defined as consciousness shared by individuals within a society. This identified factor suggests that the consumers like buying products from companies that give something back to society. The company's society welfare impacts the consumers' buying pattern (Kuamr and Dash, 2015; Kukar-Kinney et al., 2016) as they are ready to pay extra for that company's product which contribute towards the welfare of the society (Kim et al., 2010; Wallace et al., 2012). 
The service providers should think about these factors for targeting their consumers in digital platform so that they can increase the consumers' trust.

\section{Conclusion and future research directions}

Rapid increase in Internet usability and speedy flow of information are impacting the consumer decision making in the digital market. This changing pattern in decision making is increasing the challenges for the online service providers for predicting the consumers' behaviour and their buying pattern. This study proposes a hierarchy model for changing pattern of consumer decision making in digital market by taking the case of India.

To achieve the intended objectives, two phased study is conducted. In the first phase, a thorough review of literature has been performed to find out the factors linked to changing pattern of consumers' decision making in the digital platform. Then, for finalizing the factors fuzzy Delphi is used, which allows to capture human bias and vagueness in data. Therefore, fuzzy Delphi method finalizes the relevant factor and sub-factors for the study. In the second phase, the priority weights of finalized factors and sub-factors are determined using fuzzy AHP. The key findings of this study are as follows: first the study developed a model which is based on the changing pattern of the consumer and that model can help the service providers to predict their consumers in digital market, which can help the online service providers in predicting their customers efficiently and target them accordingly.

Second, the results show that 'innovative and trendy' products is the first priority for consumer followed by 'brand and quality' and 'fulfilment and time energy'. It shows that consumers are much conscious about innovative and trendy products as well as brand and quality therefore, the service providers must think about these two most important factors so that they can be able to retain their consumers in their online portal. According to the findings of study, busy schedule consumers do not want to waste their energy and time and want to buy whatever they want from one platform therefore the service provider must focus on how the consumers' demands can fulfil timely. The consumers are also conscious about reputation system, information overload, price and value for money, face and risk aversion and social aspects therefore, the online service providers should concentrate on these factors so that they understand their changing pattern well. The proposed model can help the marketers and service providers in predicting customers' preferences and their changing pattern efficiently under vague surroundings. Based on the outcomes of this research work, not only the service providers can update their products and services according to consumers' needs, but they can also increase their profit and minimize their risk. 
The study has some limitations as well. The identification of factors and sub-factors linked to changing pattern of consumers' decision making in the digital platform is quite challenging. The proposed model is based on experts' judgements; thus, it needs significant evaluation. The developed model may also be applied to other country contexts with marginal revisions. In the study, the authors used Fuzzy AHP to find the priority of the factors and sub-factors, but others multi-factor methods can be employed for doing a comparative analysis of the results. Further, the interrelations among the listed factor and sub-factor of changing pattern of consumers' decision making may be explored and based on these interrelations, research hypothesis can be developed and tested in future studies.

\section{References}

Abbasi, M.S., Chandio, F.H., Soomro, A.F., \& Shah, F. (2011). Social influence, voluntariness, experience and the Internet acceptance: An extension of technology acceptance model within a south-Asian country context. Journal of Enterprise Information Management, 24(1), 30-52.

Akhter, F., Hobbs, D., \& Maamar, Z. (2005). A fuzzy logic-based system for assessing the level of business-to-consumer (B2C) trust in electronic commerce. Expert Systems with Applications, 28(4), 623-628.

Akter, S., \& Wamba, S. F. (2016). Big data analytics in E-commerce: a systematic review and agenda for future research. Electronic Markets, 26(2), 173-194.

Ashman, R., Solomon, M.R., \& Wolny, J. (2015). An old model for a new age: Consumer decision making in participatory digital culture. Journal of Customer Behaviour, 14(2), 127-146.

Auh, S., Shih, E., \& Yoon, Y. (2008). Aligning benefits with payments: A test of the pattern alignment hypothesis. Journal of Consumer Psychology, 18(4), 292-303.

Baldus, B.J., Voorhees, C., \& Calantone, R. (2015). Online brand community engagement: Scale development and validation. Journal of Business Research, 68(5), 978-985.

Barrows, G., \& Ollivier, H. (2018). Cleaner firms or cleaner products? How product mix shapes emission intensity from manufacturing. Journal of Environmental Economics and Management, 88, 134-158.

Bhargave, R., Mantonakis, A., \& White, K. (2016). The cue-of-the-cloud effect: When reminders of online information availability increase purchase intentions and choice. Journal of Marketing Research, 53(5), 699-711. 
Bilgihan, A. (2016). Gen Y customer loyalty in online shopping: An integrated model of trust, user experience and branding. Computers in Human Behavior, 61, 103-113.

Bodur, H.O., Klein, N.M., \& Arora, N. (2015). Online price search: Impact of price comparison sites on offline price evaluations. Journal of Retailing, 91(1), 125-139.

Boland, W.A., Connell, P.M., \& Erickson, L.M. (2012). Children's response to sales promotions and their impact on purchase behavior. Journal of Consumer Psychology, $22(2), 272-279$.

Bouzon, M., Govindan, K., Rodriguez, C.M.T., \& Campos, L.M. (2016). Identification and analysis of reverse logistics barriers using fuzzy Delphi method and AHP. Resources, Conservation and Recycling, 108, 182-197.

Büyüközkan, G., \& Çifçi, G. (2012). A combined fuzzy AHP and fuzzy TOPSIS based strategic analysis of electronic service quality in healthcare industry. Expert Systems with Applications, 39(3), 2341-2354.

Chae, H., \& Ko, E. (2016). Customer social participation in the social networking services and its impact upon the customer equity of global fashion brands. Journal of Business Research, 69(9), 3804-3812.

Chang, A., Hsieh, S.H., \& Tseng, T.H. (2013). Online brand community response to negative brand events: the role of group eWOM. Internet Research, 23(4), 486-506.

Chang, D. Y. (1992). Extent analysis and synthetic decision. Optimization Techniques and Applications, 1(1), 352-355.

Chaparro-Peláez, J., Agudo-Peregrina, Á.F., \& Pascual-Miguel, F.J. (2016). Conjoint analysis of drivers and inhibitors of e-commerce adoption. Journal of Business Research, 69(4), $1277-1282$.

Chen, Y., Yan, X., Fan, W., \& Gordon, M. (2015). The joint moderating role of trust propensity and gender on consumers' online shopping behavior. Computers in Human Behavior, 43, 272-283.

Chiang, W.Y. (2017). Discovering customer value for marketing systems: an empirical case study. International Journal of Production Research, 55(17), 5157-5167.

Chiu, W. Y., Tzeng, G.H., \& Li, H.L. (2013). A new hybrid MCDM model combining DANP with VIKOR to improve e-store business. Knowledge-Based Systems, 37, 48-61.

Clemes, M. D., Gan, C., \& Zhang, J. (2014). An empirical analysis of online shopping adoption in Beijing, China. Journal of Retailing and Consumer Services, 21(3), 364-375.

Close, A.G., \& Kukar-Kinney, M. (2010). Beyond buying: Motivations behind consumers' online shopping cart use. Journal of Business Research, 63(9), 986-992. 
Confos, N., Confos, N., Davis, T., \& Davis, T. (2016). Young consumer-brand relationship building potential using digital marketing. European Journal of Marketing, 50(11), 19932017.

Dağdeviren, M., \& Yüksel, İ. (2008). Developing a fuzzy analytic hierarchy process (AHP) model for behavior-based safety management. Information Sciences, 178(6), 1717-1733.

Darley, W.K., Blankson, C., \& Luethge, D.J. (2010). Toward an integrated framework for online consumer behavior and decision-making process: A review. Psychology \& Marketing, 27(2), 94-116.

Doherty, N.F., \& Ellis-Chadwick, F. (2010). Internet retailing: the past, the present and the future. International Journal of Retail \& Distribution Management, 38(11/12), 943-965.

Du, S., Bhattacharya, C.B., \& Sen, S. (2010). Maximizing business returns to corporate social responsibility (CSR): The role of CSR communication. International Journal of Management Reviews, 12(1), 8-19.

Efe, B. (2016). An integrated fuzzy multi criteria group decision making approach for ERP system selection. Applied Soft Computing, 38, 106-117.

Eisingerich, A.B., Chun, H.H., Liu, Y., Jia, H.M., \& Bell, S.J. (2015). Why recommend a brand face-to-face but not on Facebook? How word-of-mouth on online social sites differs from traditional word-of-mouth. Journal of Consumer Psychology, 25(1), 120128.

Erevelles, S., Fukawa, N., \& Swayne, L. (2016). Big Data consumer analytics and the transformation of marketing. Journal of Business Research, 69(2), 897-904.

Essoussi, L.H., \& Linton, J. D. (2010). New or recycled products: how much are consumers willing to pay? Journal of Consumer Marketing, 27(5), 458-468.

Filieri, R. (2015). What makes online reviews helpful? A diagnosticity-adoption framework to explain informational and normative influences in e-WOM. Journal of Business Research, 68(6), 1261-1270.

Fullam, J. (2017). Becoming a youth activist in the internet age: a case study on social media activism and identity development. International Journal of Qualitative Studies in Education, 30(4), 406-422.

Gandhi, S., Mangla, S.K., Kumar, P., \& Kumar, D. (2016). A combined approach using AHP and DEMATEL for evaluating success factors in implementation of green supply chain management in Indian manufacturing industries. International Journal of Logistics Research and Applications, 19(6), 537-561. 
Govindan, K., Mangla, S.K., \& Luthra, S. (2017). Prioritising indicators in improving supply chain performance using fuzzy AHP: insights from the case example of four Indian manufacturing companies. Production Planning \& Control, 28(6-8), 552-573.

Grosso, C., Forza, C., \& Trentin, A. (2017). Supporting the social dimension of shopping for personalized products through online sales configurators. Journal of Intelligent Information Systems, 49(1), 9-35.

Gupta, R., Ponnuru, K., Kumar, A., \& Trivedi, S. K. (2017). Factors identification of online reputation and relationship with trust: a study of generation Y. International Journal of Business Information Systems, 26(2), 151-165.

Harris, L.C. (2010). Fraudulent consumer returns: exploiting retailers' return policies. European Journal of Marketing, 44(6), 730-747.

Havakhor, T., Soror, A. A., \& Sabherwal, R. (2018). Diffusion of knowledge in social media networks: effects of reputation mechanisms and distribution of knowledge roles. Information systems journal, 28(1), 104-141.

Heitz-Spahn, S. (2013). Cross-channel free-riding consumer behavior in a multichannel environment: An investigation of shopping motives, sociodemographics and product categories. Journal of Retailing and Consumer Services, 20(6), 570-578.

Hung, Y.H., Huang, T.L., Hsieh, J.C., Tsuei, H.J., Cheng, C.C., \& Tzeng, G.H. (2012). Online reputation management for improving marketing by using a hybrid MCDM model. Knowledge-Based Systems, 35, 87-93.

Ishikawa, A., Amagasa, M., Shiga, T., Tomizawa, G., Tatsuta, R. and Mieno, H. (1993). The max-min Delphi method and fuzzy Delphi method via fuzzy integration. Fuzzy sets and systems, 55(3), 241-253.

Jiang, P., Balasubramanian, S.K., \& Lambert, Z. V. (2015). Responses to customized products: The consumers' behavioral intentions. Journal of Services Marketing, 29(4), 314-326.

Joshi, K.P., \& Alur, S. (2016). Enhanced Selling on Digital Space via Matching Buyer and Seller Preferences Using Fuzzy MCDM Method. In Fuzzy Optimization and MultiCriteria Decision Making in Digital Marketing (pp. 148-158). IGI Global.

Kabir, G., \& Akhtar Hasin, A. (2011). Evaluation of customer oriented success factors in mobile commerce using fuzzy AHP. Journal of Industrial Engineering and Management, 4(2), 361-386. 
Kacen, J.J., Hess, J.D., \& Chiang, W.Y.K. (2013). Bricks or clicks? Consumer attitudes toward traditional stores and online stores. Global Economics and Management Review, $18(1), 12-21$.

Kaltenrieder, P., D’Onofrio, S., \& Portmann, E. (2015). Applying the Fuzzy Analytical Network Process in Digital Marketing. Fuzzy Optimization and Multi-Criteria Decision Making in Digital Marketing, 202.

Kang, D., Jang, W., \& Park, Y. (2016). Evaluation of e-commerce websites using fuzzy hierarchical TOPSIS based on ES-QUAL. Applied Soft Computing, 42, 53-65.

Khare, A. (2012). Impact of consumer decision-making styles on Indian consumers' mall shopping behaviour. International Journal of Indian Culture and Business Management, 5(3), 259-279.

Kim, H.R., Lee, M., Lee, H.T., \& Kim, N.M. (2010). Corporate social responsibility and employee-company identification. Journal of Business Ethics, 95(4), 557-569.

Kim, H.W., Xu, Y., \& Gupta, S. (2012). Which is more important in Internet shopping, perceived price or trust? Electronic Commerce Research and Applications, 11(3), 241252.

Kim, J.U., Kim, W.J., \& Park, S.C. (2010). Consumer perceptions on web advertisements and motivation factors to purchase in the online shopping. Computers in Human Behavior, 26(5), 1208-1222.

Kukar-Kinney, M., Scheinbaum, A.C., \& Schaefers, T. (2016). Compulsive buying in online daily deal settings: An investigation of motivations and contextual elements. Journal of Business Research, 69(2), 691-699.

Kumar, A., \& Dash, M.K. (2015). Fuzzy Structural Models and Based Applications in Digital Marketplace. Fuzzy Optimization and Multi-Criteria Decision Making in Digital Marketing, 59.

Kumar, A., Luthra, S., Khandelwal, D.K., Mehta, R., Chaudhary, N., \& Bhatia, S. (2017). Measuring and improving customer retention at authorised automobile workshops after free services. Journal of Retailing and Consumer Services, 39, 93-102.

Lambert, A., \& Desmond, J. (2013). Loyal now, but not forever! A study of narcissism and male consumer-brand relationships. Psychology \& Marketing, 30(8), 690-706.

Lee, J., Park, D. H., \& Han, I. (2011). The different effects of online consumer reviews on consumers' purchase intentions depending on trust in online shopping malls: An advertising perspective. Internet Research, 21(2), 187-206. 
Lee, S., \& Ahn, H. (2009). Fuzzy cognitive map based on structural equation modeling for the design of controls in business-to-consumer e-commerce web-based systems. Expert Systems with Applications, 36(7), 10447-10460.

Li, Y., Xu, L., \& Li, D. (2013). Examining relationships between the return policy, product quality, and pricing strategy in online direct selling. International Journal of Production Economics, 144(2), 451-460.

Lissitsa, S., \& Kol, O. (2016). Generation X vs. Generation Y-A decade of online shopping. Journal of Retailing and Consumer Services, 31, 304-312.

Liu, C.C., \& Chen, S.Y. (2009). Prioritization of digital capital measures in recruiting website for the national armed forces. Expert Systems with Applications, 36(5), 9415-9421.

Liu, X., Burns, A.C., \& Hou, Y. (2013). Comparing online and in-store shopping behavior towards luxury goods. International Journal of Retail \& Distribution Management, 41(11/12), 885-900.

Lu, A.C.C., \& Gursoy, D. (2015). A conceptual model of consumers' online tourism confusion. International Journal of Contemporary Hospitality Management, 27(6), 13201342.

Lu, A.C.C., Gursoy, D., \& Lu, C.Y.R. (2016). Antecedents and outcomes of consumers' confusion in the online tourism domain. Annals of Tourism Research, 57, 76-93.

MacInnis, D.J., \& Folkes, V.S. (2017). Humanizing brands: When brands seem to be like me, part of me, and in a relationship with me. Journal of Consumer Psychology, 27(3), 355374.

Mafael, A., Gottschalk, S.A., \& Kreis, H. (2016). Examining Biased Assimilation of Brandrelated Online Reviews. Journal of Interactive Marketing, 36, 91-106.

Mangla, S.K., Kumar, P., \& Barua, M.K. (2015). Prioritizing the responses to manage risks in green supply chain: An Indian plastic manufacturer perspective. Sustainable Production and Consumption, 1, 67-86.

Mangla, S.K., Kumar, P., \& Barua, M.K. (2016). An integrated methodology of FTA and fuzzy AHP for risk assessment in green supply chain. International Journal of Operational Research, 25(1), 77-99.

Mardani, A., Zavadskas, E. K., Streimikiene, D., Jusoh, A., Nor, K.M., \& Khoshnoudi, M. (2016). Using fuzzy multiple criteria decision-making approaches for evaluating energy saving technologies and solutions in five-star hotels: A new hierarchical framework. Energy, 117, 131-148. 
McDonald, M., \& Wilson, H. (2016). Marketing Plans: How to prepare them, how to profit from them. John Wiley \& Sons.

Meeran, S., Jahanbin, S., Goodwin, P., \& Neto, J.Q.F. (2017). When do changes in consumer preferences make forecasts from choice-based conjoint models unreliable? European Journal of Operational Research, 258(2), 512-524.

Mittelman, M., Mittelman, M., Andrade, E.B., \& Andrade, E.B. (2017). Product order affects consumer preferences for variety bundles. European Journal of Marketing, 51(5/6), 869884.

Mohanty, B.K., \& Passi, K. (2010). Agent based e-commerce systems that react to buyers' feedbacks-A fuzzy approach. International Journal of Approximate Reasoning, 51(8), 948-963.

Morid, M.A., \& Shajari, M. (2012). An enhanced e-commerce trust model for community based centralized systems. Electronic Commerce Research, 12(4), 409-427.

Müller, H., \& Diels, J. (2016). Reversing the Similarity Effect in Stock- Outs: A New Look at a Renowned Phenomenon in Consumers' Brand Switching Behavior. Psychology \& Marketing, 33(1), 48-59.

Naili, M., Boubetra, A., \& Tari, A. (2015). Fuzzy Multi-Criteria Decision-Making Methods for E-Commerce Issues. Fuzzy Optimization and Multi-Criteria Decision Making in Digital Marketing, 20.

Packard, G.M., \& Wooten, D. B. (2013). Compensatory knowledge signaling in consumer word-of-mouth. Journal of Consumer Psychology, 23 (4), 434-450.

Pappas, I.O., Kourouthanassis, P.E., Giannakos, M.N., \& Chrissikopoulos, V. (2016). Explaining online shopping behavior with fsQCA: The role of cognitive and affective perceptions. Journal of Business Research, 69(2), 794-803.

Pappas, I.O., Kourouthanassis, P.E., Giannakos, M.N., \& Lekakos, G. (2017). The interplay of online shopping motivations and experiential factors on personalized e-commerce: A complexity theory approach. Telematics and Informatics, 34(5), 730-742.

Pappas, N. (2016). Marketing strategies, perceived risks, and consumer trust in online buying behaviour. Journal of Retailing and Consumer Services, 29, 92-103.

Prakash, G., Singh, P. K., \& Yadav, R. (2018). Application of Consumer Style Inventory (CSI) to predict young Indian consumer's intention to purchase organic food products. Food Quality and Preference, 68, 90-97. 
Rekik, R., Kallel, I., \& Alivmi, A.M. (2016, October). Ranking criteria based on fuzzy ANP for assessing E-commerce web sites. In Systems, Man, and Cybernetics (SMC), 2016 IEEE International Conference on (pp. 003469-003474). IEEE.

Rezaei, S., Ali, F., Amin, M., \& Jayashree, S. (2016). Online impulse buying of tourism products: The role of web site personality, utilitarian and hedonic web browsing. Journal of Hospitality and Tourism Technology, 7(1), 60-83.

Richa, D. (2012). Impact of demographic factors of consumers on online shopping behaviour: A study of consumers in India. International Journal of Engineering and Management Sciences, 3(1), 43-52.

Röllecke, F. J., Huchzermeier, A., \& Schröder, D. (2018). Returning Customers: The Hidden Strategic Opportunity of Returns Management. California Management Review, 60(2), 176-203.

Royle, J., \& Laing, A. (2014). The digital marketing skills gap: Developing a Digital Marketer Model for the communication industries. International Journal of Information Management, 34(2), 65-73.

Saaty, T.L. (1980). The Analytic Hierarchy Process: Planning, Priority Setting, Resources Allocation. McGraw, New York

Sahney, S. (2015). Critical success factors in online retail-an application of quality function deployment and interpretive structural modeling. International Journal of Business and Information, 3(1), 144-163.

Samuel, L.H.S., Balaji, M. S., \& Kok Wei, K. (2015). An investigation of online shopping experience on trust and behavioral intentions. Journal of Internet Commerce, 14(2), 233254.

Şengül, Ü., \& Eren, M. (2015). Selection of Digital Marketing Tools Using Fuzzy AHPFuzzy TOPSIS. Fuzzy Optimization and Multi-Criteria Decision Making in Digital Marketing, 97.

Shams, R., Alpert, F., \& Brown, M. (2015). Consumer perceived brand innovativeness: conceptualization and operationalization. European Journal of Marketing, 49(9/10), 1589-1615.

Shaouf, A., Lü, K., \& Li, X. (2016). The effect of web advertising visual design on online purchase intention: An examination across gender. Computers in Human Behavior, 60, 622-634.

Silva, R.V.D., \& Alwi, S.F.S. (2008). Online brand attributes and online corporate brand images. European Journal of Marketing, 42(9/10), 1039-1058. 
Sohaib, O., \& Naderpour, M. (2017, July). Decision making on adoption of cloud computing in e-commerce using fuzzy TOPSIS. In Fuzzy Systems (FUZZ-IEEE), 2017 IEEE International Conference on (pp. 1-6). IEEE.

Srinivasan, S., Rutz, O. J., \& Pauwels, K. (2016). Paths to and off purchase: quantifying the impact of traditional marketing and online consumer activity. Journal of the Academy of Marketing Science, 44(4), 440-453.

Tan, K.S., Chong, S.C., Lin, B., \& Eze, U.C. (2010). Internet-based ICT adoption among SMEs: Demographic versus benefits, barriers, and adoption intention. Journal of Enterprise Information Management, 23(1), 27-55.

Tavana, M., Momeni, E., Rezaeiniya, N., Mirhedayatian, S. M., \& Rezaeiniya, H. (2013). A novel hybrid social media platform selection model using fuzzy ANP and COPRAS-G. Expert Systems with Applications, 40(14), 5694-5702.

Thakur, R., \& Srivastava, M. (2015). A study on the impact of consumer risk perception and innovativeness on online shopping in India. International Journal of Retail \& Distribution Management, 43(2), 148-166.

Tjiptono, F., Arli, D., \& Bucic, T. (2014). Consumer confusion proneness: insights from a developing economy. Marketing Intelligence \& Planning, 32(6), 722-734.

Vassileva, B. (2017). Marketing 4.0: How Technologies Transform Marketing Organisation. Obuda University E-Bulletin, 7(1), 47-56.

Veisi, H., Liaghati, H., \& Alipour, A. (2016). Developing an ethics-based approach to indicators of sustainable agriculture using analytic hierarchy process (AHP). Ecological Indicators, 60, 644-654.

Vidal, L.A., Marle, F., \& Bocquet, J.C. (2011). Using a Delphi process and the Analytic Hierarchy Process (AHP) to evaluate the complexity of projects. Expert Systems with Applications, 38(5), 5388-5405.

Wagner, G., Schramm-Klein, H., \& Steinmann, S. (2017). Consumers' attitudes and intentions toward Internet-enabled TV shopping. Journal of Retailing and Consumer Services, 34, 278-286.

Wallace, E., Buil, I., \& De Chernatony, L. (2012). Facebook 'friendship' and brand advocacy. Journal of Brand Management, 20(2), 128-146.

Wang, C. H. (2013). Incorporating customer satisfaction into the decision-making process of product configuration: a fuzzy Kano perspective. International Journal of Production Research, 51(22), 6651-6662. 
Wang, G., Dou, W., \& Zhou, N. (2008). Consumption attitudes and adoption of new consumer products: a contingency approach. European Journal of Marketing, 42(1/2), 238-254.

Wang, H. Y., \& Wang, S. H. (2010). Predicting mobile hotel reservation adoption: Insight from a perceived value standpoint. International Journal of Hospitality Management, 29(4), 598-608.

Wang, L., Chu, J., \& Wu, J. (2007). Selection of optimum maintenance strategies based on a fuzzy analytic hierarchy process. International Journal of Production Economics, 107(1), 151-163.

Wu, J. F., Wu, J. F., Chang, Y. P., \& Chang, Y. P. (2016). Multichannel integration quality, online perceived value and online purchase intention: A perspective of land-based retailers. Internet Research, 26(5), 1228-1248.

$\mathrm{Wu}, \mathrm{W}$. W. (2012). Segmenting critical factors for successful knowledge management implementation using the fuzzy DEMATEL method. Applied Soft Computing, 12(1), 527535.

Wu, W.Z., \& Zhang, W.X. (2004). Constructive and axiomatic approaches of fuzzy approximation operators. Information Sciences, 159(3), 233-254.

Xiang, Z., Magnini, V.P., \& Fesenmaier, D.R. (2015). Information technology and consumer behavior in travel and tourism: Insights from travel planning using the internet. Journal of Retailing and Consumer Services, 22, 244-249.

Xu, X., Zeng, S., \& He, Y. (2017). The influence of e-services on customer online purchasing behavior toward remanufactured products. International Journal of Production Economics, 187, 113-125.

Yang, S., Song, Y., \& Tong, S. (2017). Sustainable retailing in the fashion industry: A systematic literature review. Sustainability, 9(7), 1-19.

Ye, Q., Law, R., Gu, B., \& Chen, W. (2011). The influence of user-generated content on traveler behavior: An empirical investigation on the effects of e-word-of-mouth to hotel online bookings. Computers in Human Behavior, 27(2), 634-639.

Yeh, C.H., Wang, Y. S., \& Yieh, K. (2016). Predicting smartphone brand loyalty: consumer value and consumer-brand identification perspectives. International Journal of Information Management, 36(3), 245-257.

Yeo, V.C.S., Goh, S.K., \& Rezaei, S. (2017). Consumer experiences, attitude and behavioral intention toward online food delivery (OFD) services. Journal of Retailing and Consumer Services, 35, 150-162. 
Zadeh, L.A. (1965). Fuzzy sets. Information and Control, 8(3), 338-353.

Zandi, F., \& Tavana, M. (2011). A fuzzy group quality function deployment model for eCRM framework assessment in agile manufacturing. Computers \& Industrial Engineering, 61(1), 1-19.

Zhu, F., \& Zhang, X. (2010). Impact of online consumer reviews on sales: The moderating role of product and consumer characteristics. Journal of Marketing, 74(2), 133-148.

\section{$\underline{\text { Appendix A1 }}$}

\section{Fuzzy Delphi Questionnaire}

Please indicate the importance of factors on the basis of the following scale: Extremely Important (EI), Important (I), Normal (N), Unimportant (UI), Extremely Unimportant (EUI).

Please tick $(\sqrt{ })$ in appropriate box

\begin{tabular}{|c|c|c|c|c|c|}
\hline & 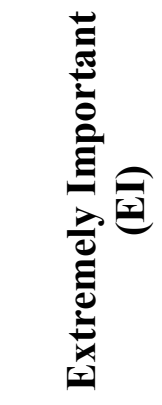 & 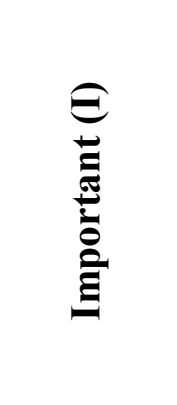 & 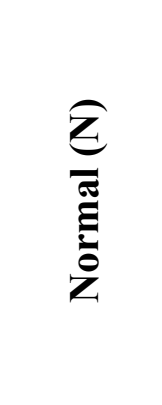 & 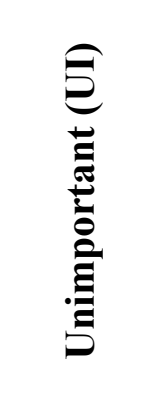 & 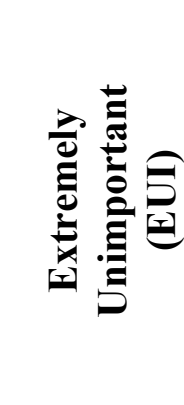 \\
\hline & $\begin{array}{c}(0.7,0.9, \\
0.9)\end{array}$ & $\begin{array}{c}(0.5,0.7 \\
0.9)\end{array}$ & $\begin{array}{c}(0.3,0.5, \\
0.7)\end{array}$ & $\begin{array}{c}(0.1,0.3, \\
0.5)\end{array}$ & $\begin{array}{l}(0.1,0.1 \\
0.3)\end{array}$ \\
\hline 1. The trendiest products & & & & & \\
\hline 2. Customize products & & & & & \\
\hline 3. Up-to-date products & & & & & \\
\hline ------- & \multicolumn{5}{|c|}{------- } \\
\hline $\begin{array}{l}\text { 35. Feel more insure } \\
\text { during online purchasing }\end{array}$ & & & & & \\
\hline
\end{tabular}

\section{$\underline{\text { Appendix A2 }}$}

\section{AHP Questionnaire}

\section{Instructions:}

Suppose we take two parameters, namely, reputation system and information overload to comparison. If one thinks that the strategic factor reputation system is strongly important than information overload in terms of changing pattern of consumer decision making in the digital 
market, then you can mark "5" which means "reputation system" is 5 times more important than "information overload".

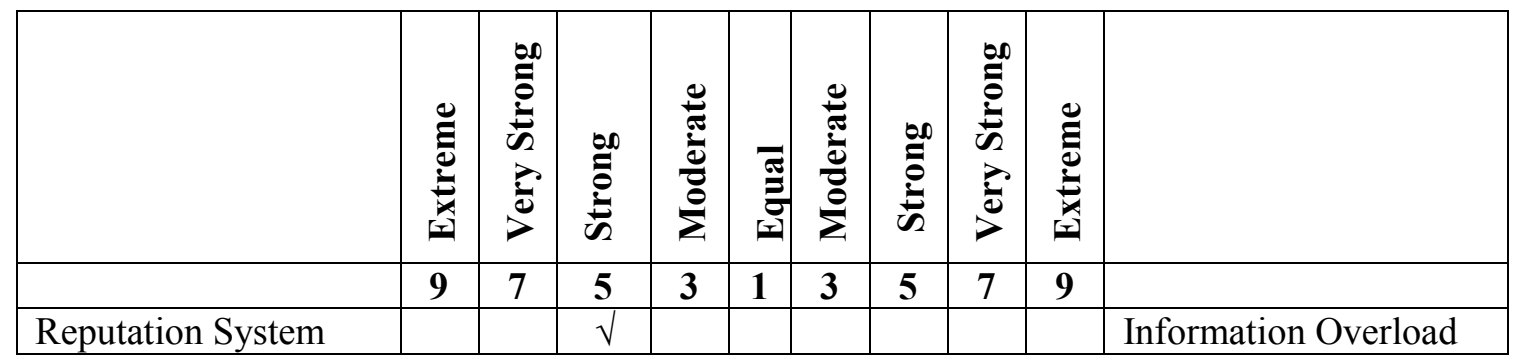

Start from here....

Please tick $(\sqrt{ })$ in appropriate box

\begin{tabular}{|c|c|c|c|c|c|c|c|c|c|c|}
\hline Goal & \multicolumn{10}{|c|}{ Importance } \\
\hline Main - factors & & 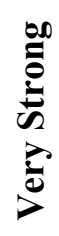 & 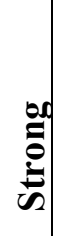 & 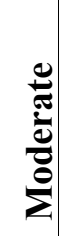 & 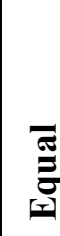 & 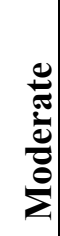 & 苞 & $\begin{array}{l}0 \\
0 \\
0 \\
0 \\
0 \\
0 \\
0 \\
0\end{array}$ & 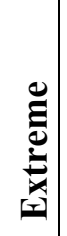 & Main - factors \\
\hline & 9 & 7 & 5 & 3 & 1 & 3 & 5 & 7 & 9 & \\
\hline Innovative and Trendy & & & & & & & & & & Brand and Quality \\
\hline Innovative and Trendy & & & & & & & & & & Fulfilment and Time Energy \\
\hline Innovative and Trendy & & & & & & & & & & Reputation System \\
\hline Innovative and Trendy & & & & & & & & & & Information Overload \\
\hline Innovative and Trendy & & & & & & & & & & Price and Value for Money \\
\hline Innovative and Trendy & & & & & & & & & & Face and Risk Aversion \\
\hline Innovative and Trendy & & & & & & & & & & Social Aspects \\
\hline Brand and Quality & & & & & & & & & & Fulfilment and Time Energy \\
\hline Brand and Quality & & & & & & & & & & Reputation System \\
\hline Brand and Quality & & & & & & & & & & Information Overload \\
\hline Brand and Quality & & & & & & & & & & Price and Value for Money \\
\hline Brand and Quality & & & & & & & & & & Face and Risk Aversion \\
\hline Brand and Quality & & & & & & & & & & Social Aspects \\
\hline $\begin{array}{l}\text { Fulfilment and Time } \\
\text { Energy }\end{array}$ & & & & & & & & & & Reputation System \\
\hline $\begin{array}{l}\text { Fulfilment and Time } \\
\text { Energy }\end{array}$ & & & & & & & & & & Information Overload \\
\hline $\begin{array}{l}\text { Fulfilment and Time } \\
\text { Energy }\end{array}$ & & & & & & & & & & Price and Value for Money \\
\hline $\begin{array}{l}\text { Fulfilment and Time } \\
\text { Energy }\end{array}$ & & & & & & & & & & Face and Risk Aversion \\
\hline $\begin{array}{l}\text { Fulfilment and Time } \\
\text { Energy }\end{array}$ & & & & & & & & & & Social Aspects \\
\hline Reputation System & & & & & & & & & & Information Overload \\
\hline Reputation System & & & & & & & & & & Price and Value for Money \\
\hline Reputation System & & & & & & & & & & Face and Risk Aversion \\
\hline Reputation System & & & & & & & & & & Social Aspects \\
\hline Information Overload & & & & & & & & & & Price and Value for Money \\
\hline
\end{tabular}




\begin{tabular}{|l|l|l|l|l|l|l|l|l|l|l|}
\hline Information Overload & & & & & & & & & & Face and Risk Aversion \\
\hline Information Overload & & & & & & & & & & Social Aspects \\
\hline $\begin{array}{l}\text { Price and Value for } \\
\text { Money }\end{array}$ & & & & & & & & & & Face and Risk Aversion \\
\hline $\begin{array}{l}\text { Price and Value for } \\
\text { Money }\end{array}$ & & & & & & & & & & Social Aspects \\
\hline Face and Risk Aversion & & & & & & & & & & Social Aspects \\
\hline
\end{tabular}

\section{$\underline{\text { Appendix A3 }}$}

\section{Calculating extent values using extent analysis method}

Calculating extent values by using step 2 of Extent Analysis method through Eq. (8) to Eq.

(10):

$\xi\left(\mathrm{M}_{1} \geq \mathrm{M}_{2}\right)=1, \xi\left(\mathrm{M}_{1} \geq \mathrm{M}_{3}\right)=1, \xi\left(\mathrm{M}_{1} \geq \mathrm{M}_{4}\right)=1, \xi\left(\mathrm{M}_{1} \geq \mathrm{M}_{5}\right)=1, \xi\left(\mathrm{M}_{1} \geq \mathrm{M}_{6}\right)=1, \xi\left(\mathrm{M}_{1} \geq \mathrm{M}_{7}\right)=1$, $\xi\left(\mathrm{M}_{1} \geq \mathrm{M}_{8}\right)=1$

$\xi\left(\mathrm{M}_{2} \geq \mathrm{M}_{1}\right)=0.91, \xi\left(\mathrm{M}_{2} \geq \mathrm{M}_{3}\right)=1, \xi\left(\mathrm{M}_{2} \geq \mathrm{M}_{4}\right)=1, \xi\left(\mathrm{M}_{2} \geq \mathrm{M}_{5}\right)=1, \xi\left(\mathrm{M}_{2} \geq \mathrm{M}_{6}\right)=1, \xi\left(\mathrm{M}_{2} \geq \mathrm{M}_{7}\right)$ $=1, \xi\left(\mathrm{M}_{2} \geq \mathrm{M}_{8}\right)=1$

$\xi\left(\mathrm{M}_{3} \geq \mathrm{M}_{1}\right)=0.87, \xi\left(\mathrm{M}_{3} \geq \mathrm{M}_{2}\right)=0.95, \xi\left(\mathrm{M}_{3} \geq \mathrm{M}_{4}\right)=1, \quad \xi\left(\mathrm{M}_{3} \geq \mathrm{M}_{5}\right)=1, \quad \xi\left(\mathrm{M}_{3} \geq \mathrm{M}_{6}\right)=1, \xi$ $\left(\mathrm{M}_{3} \geq \mathrm{M}_{7}\right)=1, \xi\left(\mathrm{M}_{3} \geq \mathrm{M}_{8}\right)=1$

$\xi\left(\mathrm{M}_{4} \geq \mathrm{M}_{1}\right)=0.85, \xi\left(\mathrm{M}_{4} \geq \mathrm{M}_{2}\right)=0.93, \xi\left(\mathrm{M}_{4} \geq \mathrm{M}_{3}\right)=0.98, \xi\left(\mathrm{M}_{4} \geq \mathrm{M}_{5}\right)=1, \xi\left(\mathrm{M}_{4} \geq \mathrm{M}_{6}\right)=1, \xi$ $\left(\mathrm{M}_{4} \geq \mathrm{M}_{7}\right)=1, \xi\left(\mathrm{M}_{4} \geq \mathrm{M}_{8}\right)=1$

$\xi\left(\mathrm{M}_{5} \geq \mathrm{M}_{1}\right)=0.84, \quad \xi\left(\mathrm{M}_{5} \geq \mathrm{M}_{2}\right)=0.90, \quad \xi\left(\mathrm{M}_{5} \geq \mathrm{M}_{3}\right)=0.95, \quad \xi\left(\mathrm{M}_{5} \geq \mathrm{M}_{4}\right)=0.97, \quad \xi\left(\mathrm{M}_{5} \geq \mathrm{M}_{6}\right)=1, \quad \xi$ $\left(\mathrm{M}_{5} \geq \mathrm{M}\right)=1, \xi\left(\mathrm{M}_{5} \geq \mathrm{M}_{8}\right)=1$

$\xi\left(\mathrm{M}_{6} \geq \mathrm{M}_{1}\right)=0.77, \xi\left(\mathrm{M}_{6} \geq \mathrm{M}_{2}\right)=0.84, \xi\left(\mathrm{M}_{6} \geq \mathrm{M}_{3}\right)=.088, \xi\left(\mathrm{M}_{6} \geq \mathrm{M}_{4}\right)=0.90, \xi\left(\mathrm{M}_{6} \geq \mathrm{M}_{5}\right)=0.93, \xi$ $\left(\mathrm{M}_{6} \geq \mathrm{M}_{7}\right)=1, \xi\left(\mathrm{M}_{6} \geq \mathrm{M}_{8}\right)=1$

$\xi\left(\mathrm{M}_{7} \geq \mathrm{M}_{1}\right)=0.72, \xi\left(\mathrm{M}_{7} \geq \mathrm{M}_{2}\right)=0.78, \xi\left(\mathrm{M}_{7} \geq \mathrm{M}_{3}\right)=0.82, \xi\left(\mathrm{M}_{7} \geq \mathrm{M}_{4}\right)=0.84, \quad \xi\left(\mathrm{M}_{7} \geq \mathrm{M}_{5}\right)=0.87, \xi$ $\left(\mathrm{M}_{7} \geq \mathrm{M}_{6}\right)=0.93, \xi\left(\mathrm{M}_{7} \geq \mathrm{M}_{8}\right)=0.99$

$\xi\left(\mathrm{M}_{8} \geq \mathrm{M}_{1}\right)=0.75, \xi\left(\mathrm{M}_{8} \geq \mathrm{M}_{2}\right)=0.81, \xi\left(\mathrm{M}_{8} \geq \mathrm{M}_{3}\right)=0.85, \xi\left(\mathrm{M}_{8} \geq \mathrm{M}_{4}\right)=0.86, \xi\left(\mathrm{M}_{8} \geq \mathrm{M}_{5}\right)=0.87, \xi$ $\left(\mathrm{M}_{8} \geq \mathrm{M}_{6}\right)=0.94, \xi\left(\mathrm{M}_{8} \geq \mathrm{M}_{7}\right)=1$

For following calculations, step 3 Eq. (10) to Eq. (12) are used

1. $d^{\prime}\left(\mathrm{A}_{1}\right)=\xi\left(\mathrm{M}_{1} \geq \mathrm{M}_{2}, \mathrm{M}_{3}, \mathrm{M}_{4}, \mathrm{M}_{5}, \mathrm{M}_{6}, \mathrm{M}_{7}, \mathrm{M}_{8}\right)=\min \left(\xi\left(\mathrm{M}_{1} \geq \mathrm{M}_{2}\right), \xi\left(\mathrm{M}_{1} \geq \mathrm{M}_{3}\right), \xi\left(\mathrm{M}_{1} \geq \mathrm{M}_{4}\right), \xi\right.$ $\left.\left(\mathrm{M}_{1} \geq \mathrm{M}_{5}\right), \xi\left(\mathrm{M}_{1} \geq \mathrm{M}_{6}\right), \xi\left(\mathrm{M}_{1} \geq \mathrm{M}_{7}\right), \xi\left(\mathrm{M}_{1} \geq \mathrm{M}_{8}\right)\right)=\min (1,1,1,1,1,1,1)=1$

2. $d^{\prime}\left(\mathrm{A}_{2}\right)=\xi\left(\mathrm{M}_{2} \geq \mathrm{M}_{1}, \mathrm{M}_{3}, \mathrm{M}_{4}, \mathrm{M}_{5}, \mathrm{M}_{6}, \mathrm{M}_{7}, \mathrm{M}_{8}\right)=\min \left(\xi\left(\mathrm{M}_{2} \geq \mathrm{M}_{1}\right), \xi\left(\mathrm{M}_{2} \geq \mathrm{M}_{3}\right), \xi\left(\mathrm{M}_{2} \geq \mathrm{M}_{4}\right), \xi\right.$ $\left.\left(\mathrm{M}_{2} \geq \mathrm{M}_{5}\right), \xi\left(\mathrm{M}_{2} \geq \mathrm{M}_{6}\right), \xi\left(\mathrm{M}_{2} \geq \mathrm{M}_{7}\right), \xi\left(\mathrm{M}_{2} \geq \mathrm{M}_{8}\right)\right)=\min (.91,1,1,1,1,1,1)=.91$

3. $d^{\prime}\left(\mathrm{A}_{3}\right)=\xi\left(\mathrm{M}_{3} \geq \mathrm{M}_{1}, \mathrm{M}_{2}, \mathrm{M}_{4}, \mathrm{M}_{5}, \mathrm{M}_{6}, \mathrm{M}_{7}, \mathrm{M}_{8}\right)=\min \left(\xi\left(\mathrm{M}_{3} \geq \mathrm{M}_{1}\right), \xi\left(\mathrm{M}_{3} \geq \mathrm{M}_{2}\right), \xi\left(\mathrm{M}_{3} \geq \mathrm{M}_{4}\right), \xi\right.$ $\left.\left(\mathrm{M}_{3} \geq \mathrm{M}_{5}\right), \xi\left(\mathrm{M}_{3} \geq \mathrm{M}_{6}\right), \xi\left(\mathrm{M}_{3} \geq \mathrm{M}_{7}\right), \xi\left(\mathrm{M}_{3} \geq \mathrm{M}_{8}\right)\right)=\min (.87, .95,1,1,1,1,1)=.87$

4. $d^{\prime}\left(\mathrm{A}_{4}\right)=\xi\left(\mathrm{M}_{4} \geq \mathrm{M}_{1}, \mathrm{M}_{2}, \mathrm{M}_{3}, \mathrm{M}_{5}, \mathrm{M}_{6}, \mathrm{M}_{7}, \mathrm{M}_{8}\right)=\min \left(\xi\left(\mathrm{M}_{4} \geq \mathrm{M}_{1}\right), \xi\left(\mathrm{M}_{4} \geq \mathrm{M}_{2}\right), \xi\left(\mathrm{M}_{4} \geq \mathrm{M}_{3}\right), \xi\right.$ $\left.\left(\mathrm{M}_{4} \geq \mathrm{M}_{5}\right), \xi\left(\mathrm{M}_{4} \geq \mathrm{M}_{6}\right), \xi\left(\mathrm{M}_{4} \geq \mathrm{M}_{7}\right), \xi\left(\mathrm{M}_{4} \geq \mathrm{M}_{8}\right)\right)=\min (.85, .93, .98,1,1,1,1)=.85$

5. $d^{\prime}\left(\mathrm{A}_{5}\right)=\xi\left(\mathrm{M}_{5} \geq \mathrm{M}_{1}, \mathrm{M}_{2}, \mathrm{M}_{3}, \mathrm{M}_{4}, \mathrm{M}_{6}, \mathrm{M}_{7}, \mathrm{M}_{8}\right)=\min \left(\xi\left(\mathrm{M}_{5} \geq \mathrm{M}_{1}\right), \xi\left(\mathrm{M}_{5} \geq \mathrm{M}_{2}\right), \xi\left(\mathrm{M}_{5} \geq \mathrm{M}_{3}\right), \xi\right.$ $\left.\left(\mathrm{M}_{5} \geq \mathrm{M}_{4}\right), \xi\left(\mathrm{M}_{5} \geq \mathrm{M}_{6}\right), \xi\left(\mathrm{M}_{5} \geq \mathrm{M}_{7}\right), \xi\left(\mathrm{M}_{5} \geq \mathrm{M}_{8}\right)\right)=\min (.84, .90, .94, .97,1,1,1)=.84$

6. $d^{\prime}\left(\mathrm{A}_{6}\right)=\xi\left(\mathrm{M}_{6} \geq \mathrm{M}_{1}, \mathrm{M}_{2}, \mathrm{M}_{3}, \mathrm{M}_{4}, \mathrm{M}_{5}, \mathrm{M}_{7}, \mathrm{M}_{8}\right)=\min \left(\xi\left(\mathrm{M}_{6} \geq \mathrm{M}_{1}\right), \xi\left(\mathrm{M}_{6} \geq \mathrm{M}_{2}\right), \xi\left(\mathrm{M}_{6} \geq \mathrm{M}_{3}\right), \xi\right.$ $\left.\left(\mathrm{M}_{6} \geq \mathrm{M}_{4}\right), \xi\left(\mathrm{M}_{6} \geq \mathrm{M}_{5}\right), \xi\left(\mathrm{M}_{6} \geq \mathrm{M}_{6}\right), \xi\left(\mathrm{M}_{1} \geq \mathrm{M}_{7}\right)\right)=\min (.77, .84, .88, .90, .93,1,1)=.77$

7. $d^{\prime}\left(\mathrm{A}_{7}\right)=\xi\left(\mathrm{M}_{7} \geq \mathrm{M}_{1}, \mathrm{M}_{2}, \mathrm{M}_{3}, \mathrm{M}_{4}, \mathrm{M}_{5}, \mathrm{M}_{6}, \mathrm{M}_{8}\right)=\min \left(\xi\left(\mathrm{M}_{7} \geq \mathrm{M}_{1}\right), \xi\left(\mathrm{M}_{7} \geq \mathrm{M}_{2}\right), \xi\left(\mathrm{M}_{7} \geq \mathrm{M}_{3}\right), \xi\right.$ $\left.\left(\mathrm{M}_{7} \geq \mathrm{M}_{4}\right), \xi\left(\mathrm{M}_{7} \geq \mathrm{M}_{5}\right), \xi\left(\mathrm{M}_{7} \geq \mathrm{M}_{6}\right), \xi\left(\mathrm{M}_{7} \geq \mathrm{M}_{8}\right)\right)=\min (.72, .78, .82, .84, .87, .93, .99)=.72$

8. $d^{\prime}\left(\mathrm{A}_{8}\right)=\xi\left(\mathrm{M}_{8} \geq \mathrm{M}_{1}, \mathrm{M}_{2}, \mathrm{M}_{3}, \mathrm{M}_{4}, \mathrm{M}_{5}, \mathrm{M}_{7}, \mathrm{M}_{8}\right)=\min \left(\xi\left(\mathrm{M}_{8} \geq \mathrm{M}_{1}\right), \xi\left(\mathrm{M}_{8} \geq \mathrm{M}_{2}\right), \xi\left(\mathrm{M}_{8} \geq \mathrm{M}_{3}\right), \xi\right.$ $\left.\left(\mathrm{M}_{8} \geq \mathrm{M}_{4}\right), \xi\left(\mathrm{M}_{8} \geq \mathrm{M}_{5}\right), \xi\left(\mathrm{M}_{8} \geq \mathrm{M}_{6}\right), \xi\left(\mathrm{M}_{8} \geq \mathrm{M}_{7}\right)\right)=\min (.75, .81, .85, .86, .87, .94,1)=.75$ 